\title{
WATEQ3 Geochemical Model: Thermodynamic Data for Several Additional Solids
}

Kenneth M. Krupka

Everett A. Jenne

September 1982

Prepared for the U.S. Department of Energy under Contract DE-AC06-76RLO 1830

Pacific Northwest Laboratory Operated for the U.S. Department of Energy by Battelle Memorial Institute 


\title{
DISCLAIMER
}

This report was prepared as an account of work sponsored by an agency of the United States Government. Neither the United States Government nor any agency thereof, nor any of their employees, makes any warranty, express or implied, or assumes any legal liability or responsibility for the accuracy, completeness, or usefulness of any information, apparatus, product, or process disclosed, or represents that its use would not infringe privately owned rights. Reference herein to any specific commercial product, process, or service by trade name, trademark, manufacturer, or otherwise, does not necessarily constitute or imply its endorsement, recommendation, or favoring by the United States Government or any agency thereof. The views and opinions of authors expressed herein do not necessarily state or reflect those of the United States Government or any agency thereof.

\author{
PACIFIC NORTHWEST LABORATORY \\ operated by \\ BATTELLE \\ for the \\ UNITED STATES DEPARTMENT OF ENERGY \\ under Contract DE-AC06-76RLO 1830
}

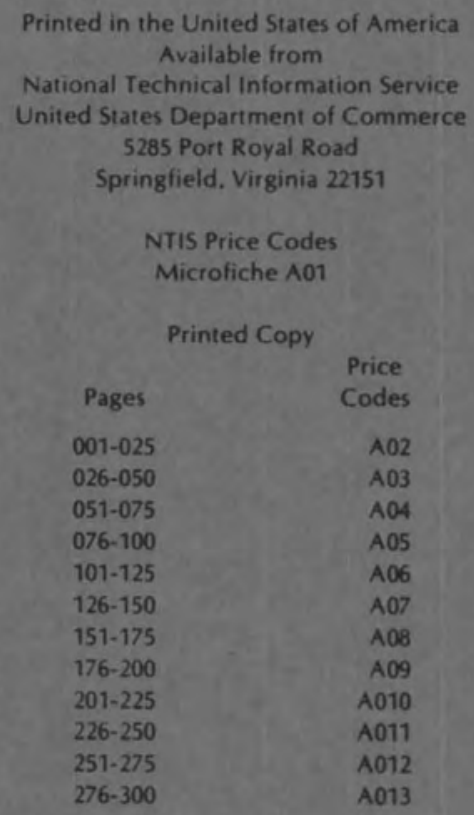


WATEQ3 GEOCHEMICAL MODEL: THERMODYNAMIC

DATA FOR SEVERAL ADDITIONAL SOLIDS

Kenneth M. Krupka

Everett $A$. Jenne

September 1982

Prepared for

the U.S. Department of Energy

under Contract DE-AC06-76RLO 1830

Pacific Northwest Laboratory

Richland, Washington 99352 


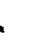

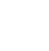




\section{ACKNOWLEDGMENTS}

The authors would like to thank A. R. Felmy and D. C. Girvin for their reviews of this document, and $W$. J. Deutsch and J. M. Zachara for many fruitful discussions on mineralogy. The authors would also like to thank P. R. Partch and B. K. Marshall for their editorial reviews of this document. This research was supported by the Department of Energy under Contract DE-AC0676RLO 1830. Support in FY1981 was provided by the Waste/Rock Interactions Technology (WRIT) Program, the Office of Nuclear Waste Isolation (ONWI), and the Terrestrial Effects of $0 i 1$ Shale Program, Office of Health and Environmental Research, and in FY1982 by the Geochemical Modeling and Nuclide/Rock/ Groundwater Interactions Studies (GMIS) Program, ONWI. 



\section{FOREWORD}

At the Pacific Northwest Laboratory, geochemical modeling activities have centered on model development and application studies. These activities are in response to the need for accurate predictions of solubility limitations and retardation by adsorption for water-soluble pollutants in laboratory and natural water/rock systems. Predicting solubility limits and retardation factors for water-soluble pollutants is crucial to technologies such as nuclear energy, oil shale development, seasonal thermal energy storage, and uranium mining, where the isolation of waste materials must be assessed.

In concert with these application efforts, modeling capabilities must be developed to enhance the competency of the geochemical model to deal with the environmental impact of wastes from these technologies. These on-going efforts include: 1) the development of a competent thermodynamic data base, which is the subject of this report; 2) critical reviews of thermodynamic data, which are necessary to generate an internally consistent and accurate data base; and 3 ) the development of an advanced computer code, which has the capabilities to model aqueous speciation, solubility controls, mass transfer, and adsorption.

Because of the need to model aqueous speciation, solubility controls and adsorption, efforts at the Pacific Northwest Laboratories have focused on developing a new geochemical model. This model, MINTEQ, is a hybridization of the extant geochemical codes WATEQ3 (Ball, Jenne and Cantrel 1981) and MINEQL (Westall, Zachary and Morel 1976). The MINTEQ model drives an efficient code for mass transfer and adsorption modeling from MINEQL, and incorporates the superior thermodynamic data base and user-oriented features of the WATEQ mode 1 series, including the revision WATEQ4. A11 previous and current thermodynamic data base enhancement activities in the WATEQ model series are transmitted to the new model. Thus the data base enhancement described in this report is an integral part of the geochemical modeling capabilities at the Pacific Northwest Laboratory.

John S. Fruchter

GMIS Program Manager 



\section{SUMMARY}

Geochemical models such as WATEQ3 can be used to model the concentrations of water-soluble pollutants that may result from the disposal of nuclear waste and retorted oil shale. However, for a model to competently deal with these water-soluble pollutants, an adequate thermodynamic data base must be provided that includes elements ident ified as important in modeling these pollutants. To this end, several minerals and related solid phases were identified that were absent from the thermodynamic data base of WATEQ3.

In this study, the thermodynamic data for the identified solids were compiled and selected from several published tabulations of thermodynamic data. For these solids, an "accepted" Gibbs free energy of formation, $\Delta G_{f, 298}^{0}$, was selected for each solid phase based on the recentness of the tabulated data and on considerations of internal consistency with respect to both the published tabulations and the existing data in WATEQ3. For those solids not included in these published tabulations, Gibbs free energies of formation were calculated from published solubility data (e.g., lepidocrocite), or were estimated (e.g., nontronite) using a free-energy summation method described by Mattigod and Sposito (1978). The "accepted" or estimated free energies were then combined with internally consistent, ancillary thermodynamic data to calculate equilibrium constants for the hydrolysis reactions of these minerals and related solid phases.

Including these values in the WATEQ3 data base increased the competency of this geochemical model in applications associated with the disposal of nuclear waste and retorted oil shale. Additional minerals and related solid phases that need to be added to the solubility submodel will be identified as modeling applications continue in these two programs. 


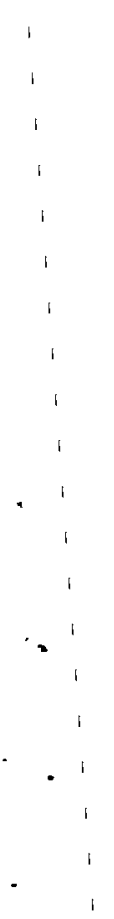




\section{CONTENTS}

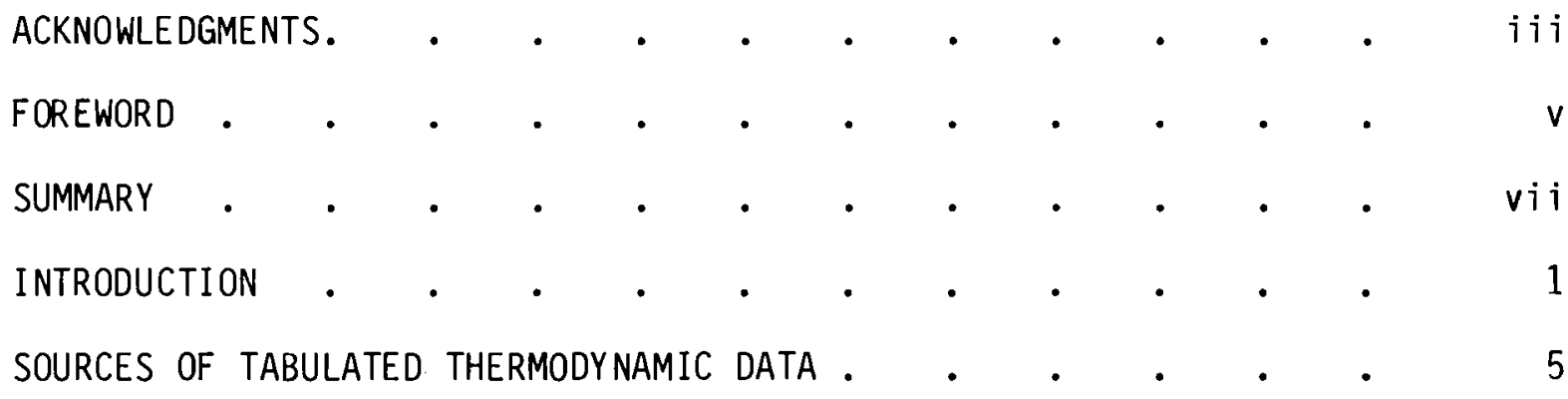

THERMODYNAMIC DATA SELECTED FOR MINERALS

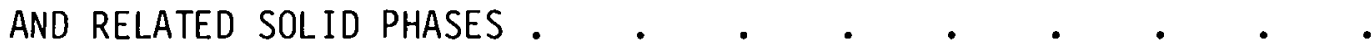

SELECTION OF $\Delta G_{f, 298}^{0}$ VALUES FOR LEPIDOCROCITE $\quad \cdot \quad \cdot \quad \cdot \quad \cdot$

ESTIMATION OF $\Delta G_{f, 298}^{0} F O R$ IDEAL END-MEMBER NONTRONITE

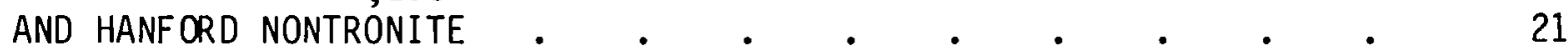

DESCRIPTION OF ESTIMATION METHODS $\quad$ • $\quad . \quad$ • $\quad$ • 21

CALCULATION OF $\Delta G_{f, 298}^{O}$ FOR IDEAL END-MEMBER

NONTRONITE

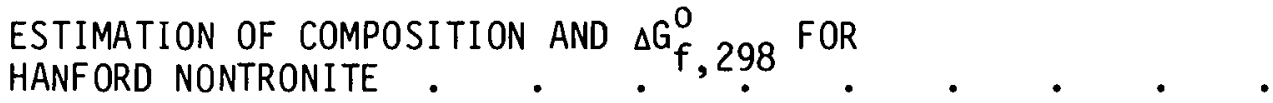

CALCULATION OF $\Delta H_{r, 298}^{0}$ AND LOG $10 \mathrm{~K}_{r, 298}^{0}$ OF THE HYDROLYSIS

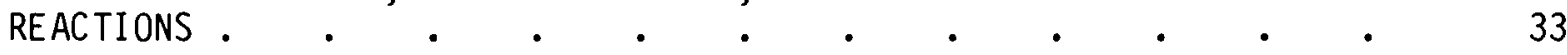

REFERENCES

APPENDIX A - EXAMPLE OF LOG ${ }_{10} K_{r, 298}^{0}$ CALCULATIONS . $\quad . \quad$. $\quad A .1$ 


\section{$\underline{\text { TABLES }}$}

1 Formula and Name of Minerals and Other Solid Phases Added to

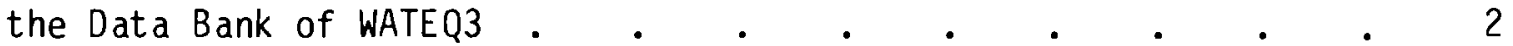

2 Accepted Thermodynamic Values for Elements Used for Calculation of Values of $\Delta \mathrm{H}_{r, 298}^{O}$ and $\log _{10} \mathrm{~K}_{r, 298}^{O} \cdot \quad \cdot \quad \cdot \quad \cdot \quad 10$

3 Accepted Thermodynamic Values for Aqueous Species Used for Calculation of Values of $\Delta \mathrm{H}_{\mathrm{r}, 298}^{\mathrm{O}}$ and $\log _{10} \mathrm{~K}_{\mathrm{r}, 298}^{0}$. . . . 11

4 Accepted Thermodynamic Values for Several Additional Solids and Water for Calculation of Values of $\Delta H_{r}^{O}, 298$ and $\log _{10} \mathrm{~K}_{r} \cdot \quad$. $\quad 12$

$5 \Delta G_{f}^{0}, 298$ for Lepidocrocite and $\log _{10} K_{r, 298}^{0}$ for Its Hydrolysis Reaction: $r-\mathrm{FeO}(\mathrm{OH})+3 \mathrm{H}^{+}=\mathrm{Fe}^{+3}+2 \mathrm{H}_{2} \mathrm{O}$. . . 20

6 Estimated $\Delta G_{f}^{0}, 298$ Values for Ideal End-Member Nontronite and for a Nontronite Composition Characteristic of Altered Columbia Plateau Basalts at the Hanford Reservation . . . 28

7 Calculated Values for Silicated Free Energies $\left(\Delta G_{f}^{0}\right.$ sil) for Estimation of $\Delta G_{f}^{O}, 298$ of Ideal End-Member Nontronite Using the Method of Tardy and Garrels (1974) . • . . . . 29

8 Hydrolysis Reactions and Computed Values of $\Delta H_{r}^{O}, 298$ and

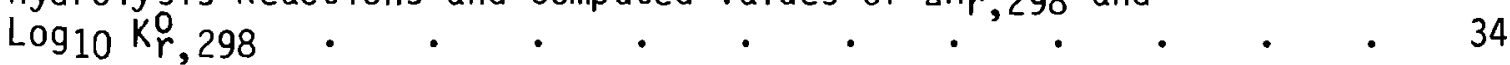

9 Hydrolysis Reactions and Computed Log10 $\mathrm{K}_{\mathrm{r}, 298}^{0}$ Values for Ideal End-Member Nontronit 


\section{INTRODUCTION}

The thermodynamic data bases for extant geochemical models require major additions to make the models competent to deal with water-soluble pollutants arising from solid and liquid wastes associated with the various energy technologies. These technologies include nuclear waste disposal, retorted oil shale disposal, seasonal thermal energy storage, and uranium mill tailings disposal.

The present effort was committed to increasing the competence of the solubility submodel for evaluating solubility equilibria in basalt aquifers and for water in contact with retorted oil shale. The WATEQ3 solubility data base, although currentiy limited to temperatures between ambient and $100^{\circ} \mathrm{C}(373 \mathrm{~K})$, is thought to be competent for most anticipated applications in the seasonal thermal energy program. A list of the additional solid phases required to provide competence for basalt aquifers, beyond those al ready in the model (Truesdell and Jones 1974; Ball, Nordstrom and Jenne 1980; Ball, Jenne and Cantre 11 1981), was generated by William Deutsch of Pacific Northwest Laboratory from the extensive mineralogical study of the Columbia Plateau basalts by Lloyd Ames (1980). The authors, with the assistance of John Zachara, Pacif ic Northwest Laboratory, compiled a list of additional solid phases that might contribute significant amounts of dissolved solids to leachates or might limit the levels of dissolved constituents in waters in contact with retorted oil shales. This list included data from the extensive mineralogical investigations of an oil shale in Israel that retorted naturally since the Eocene epoch (Gross 1977) and recent unpublished, mineralogical data from various investigations of retorted oil shales. Based on the authors' judgement that $\mathrm{Mg}$ and $\mathrm{Ca}$ oxides probably are present in freshly retorted oil shale, these oxides were also added. The minerals and other solid phases that were added to the data base of WATEQ3 are listed in Table 1 . The mineral glossary by Fleischer (1980) was used as a guide for mineralogical nomenclature. Additional minerals and related solid phases that need to be added to the solubility submodel will be identified as modeling applications continue in these two programs. 
TABLE 1. Formula and Name of Minerals and Other Solid Phases Added to the Data Bank of WATEQ3.

Formula

$\mathrm{CaO}$

$\mathrm{Ca}(\mathrm{OH})_{2}$

$\mathrm{Fe}_{0.947^{0}}$

$\gamma-\mathrm{FeO}(\mathrm{OH})$

$\mathrm{MgO}$

$\mathrm{FeAl}_{2} \mathrm{O}_{4}$

$\mathrm{MgAl}_{2} \mathrm{O}_{4}$

$\mathrm{MgFe}_{2} \mathrm{O}_{4}$

$\mathrm{Na}_{3} \mathrm{AlF}_{6}$

$\mathrm{CaSiO}_{3}$

$\mathrm{CaSiO}_{3}$

$\mathrm{Ca}_{2}\left(\mathrm{SiO}_{4}\right)$

$B-C a_{2}\left(\mathrm{SiO}_{4}\right)$

$\mathrm{Ca}_{3} \mathrm{SiO}_{5}$

$\mathrm{CaMgSiO}_{4}$

$\mathrm{Ca}_{2} \mathrm{MgSi}_{2} \mathrm{O}_{7}$

$\mathrm{Ca}_{3} \mathrm{Mg}\left(\mathrm{SiO}_{4}\right)_{2}$

$\mathrm{KAISiO}$

$\mathrm{KAIS} \mathrm{i}_{2} \mathrm{O}_{6}$

KAIS $i_{3}{ }_{8}$

$\mathrm{KAIS} \mathrm{i}_{3} \mathrm{O}_{8}$

$\mathrm{NaAlSiO}_{4}$

$\mathrm{Ca}_{2} \mathrm{Al}_{2} \mathrm{SiO}_{7}$

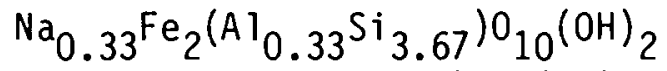

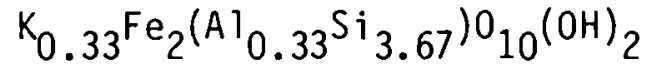

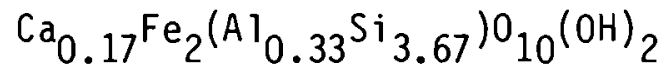

$\mathrm{Mg}_{0.17} \mathrm{Fe}_{2}\left(\mathrm{Al}_{0.33^{\mathrm{Si}}}{ }_{3.67}\right)^{0}{ }_{10}^{(\mathrm{OH})_{2}}$
Mineral Name

Lime

Portlandite

Wüstite

Lepidocrocite

Periclase

Hercynite

Spinel

Magnesio-ferrite

Cryolite

Wollastonite

Pseudowollastonite

Ca-0livine

Larnite

(No mineral name)

Monticellite

Ákermanite

Merwinite

Kalsilite (or Kaliophillite)

Leucite

Microcline

High Sanidine

Nepheline

Gehlenite

Na-Nontronite

K-Nontronite

Ca-Nontronite

$\mathrm{Mg}$-Nontronite 
In this study, the thermodynamic data for the identified solids were compiled and selected from several "standard" tabulations of thermodynamic data. An "accepted" Gibbs free energy of formation, $\Delta G_{f, 298}^{0}$, was selected for each solid phase based on the recentness of the tabulated data and on considerations of internal consistency with respect to both the published tabulations and the existing data in WATEQ3. Thermodynamic data for a few of the identified solids, which were not included in these "standard" tabulations, were obtained by other means. The Gibbs free energy of formation for lepidocrocite was calculated from published solubility data. Thermodynamic data for ideal end-member nontronite and for a nontronite typical for altered Columbia Plateau basalts were estimated using the free-energy summation method described by Mattigod and Sposito (1978). The estimation method is briefly described in this report.

The accepted values for the Gibbs free energies for formation for the identified solids were then used to calculate $\log _{10} K_{r, 298}^{0}$ values for the hydrolysis reactions involving these solids. Appendix $A$ shows an example of the calculations necessary to generate internally consistent $\Delta G_{f, 298}^{0}$ and $\log _{10} K_{r, 298}^{0}$ values based on previously selected "best" values for $S_{298}^{0}$ and $\Delta H_{f, 298}^{0}$ for the constituent elements, the ancillary components in the reaction, and the solid phase subject of the $\log _{10} K_{r, 298}^{0}$ value. These thermochemical data were added to the data base of WATEQ3 for the evaluation of solubility equilibria in basalt aquifers and for water in contact with retorted $0 i 1$ shale. This set of $\log _{10} K_{r, 298}^{0}$ values was derived primarily from measured heats of formation $\left(\Delta \mathrm{H}_{\mathrm{f}, 298}^{0}\right)^{\mathrm{O}}$ and entropy $\left(\mathrm{S}_{\mathrm{T}}^{0}\right)$ data or was estimated by analogy to other solids for which the thermodynamic data are available. It would be desirable to search the available literature for solubility data from which to compute alternate values of $\log _{10} k_{r, 298}^{0}$ for comparison with this set of $\log _{10} \mathrm{Ko}_{\mathrm{r}, 298}$ values. 



\section{SOURCES OF TABULATED THERMODYNAMIC DATA}

Thermodynamic data for the additional solid phases listed in Table 1 were compiled from several sources (CODATA Task Group 1976; Helgeson et al. 1978; Naumov, Ryzhenko and Khodakovsky 1974; Parker, Wagman and Evans 1971; Robie, Hemingway and Fisher 1978; Sadiq and Lindsay 1979; Stull and Prophet 1971; Wagman et a1. 1968, 1969, 1981). Although major differences exist in the approaches and rationales which the authors used while making these tabulations, comparisons of thermodynamic data compilations can be made to check for the most recently published data and for data consistency. In this study, these compilations of thermodynamic data were also evaluated in relation to the needs of the WATEQ3 data base for modeling geochemical systems.

Of primary importance to the WATEQ model, is the U.S. National Bureau of Standards (NBS) Technical Note Series 270 (Parker, Wagman and Evans 1971; Wagman et al. 1968, 1969, 1981). Additions to the data base of WATEQ3, by Bal1, Nordstrom and Jenne (1980) and Ball, Jenne and Cantrell (1981) were based primarily on the thermodynamic data for the constituent ions (except for $\mathrm{U}$ and $\mathrm{Mn}^{+3}$ ) given in the NBS Technical Note Series 270 tabulations. These NBS tabulations were also a major source of data for individual ion species in the earlier versions of WATEQ (Truesdell and Jones 1974), WATEQ2 (Ball, Nordstrom and Jenne 1980) and WATEQF (Plummer, Jones and Truesdel1 1976). The NBS 270 series of publications are revisions of earlier tables of thermodynamic data by Rossini et al. (1952). The interim NBS report by Parker, Wagman and Garvin (1976) was also used in the present calculations. The values tabulated in the NBS Series 270 reports and Wagman et al. (1976) are consistent with each other because the same ancillary thermodynamic data were used for all of these tables.

An international committee, the CODATA Task Group on Key Values for Thermodynamics, was formed a few years ago to prepare a recommended list of key thermodynamic data. Key values were selected and published for 74 species, which were mostly in the gaseous state, in CODATA (1976). D. D. Wagman and W. H. Evans, two principal contributors to the NBS Series 270, were also, respectively, a member and a consultant to the CODATA Task Group. Due to the nature of this committee and its task, thermodynamic values were accepted for the 
present calculations from CODATA, rather than from from the NBS 270 Series, if the values differed significantly between these two sources. Because the values from CODATA (1976) may not be completely compatible with values in the NBS Series 270, Parker, Wagman and Garvin (1976) prepared an extensive list of thermochemical values that are compatible with the CODATA values. This NBS report was prepared for the International Atomic Energy Agency to assist in the evaluation of the thermochemistry of the actinide elements. However, these two CODATA references do not provide extensive data for geologically related species and solid phases.

The summary of thermodynamic data by Robie, Hemingway and Fisher (1978) was the principal source of the data selected for the solid phases added to WATEQ3. The tables in Robie, Hemingway and Fisher (1978), designed for the geoscientist, provide a critical summary of internally consistent, thermodynamic data for minerals and other related solids. Robie, Hemingway and Fisher (1978) also used the key thermodynamic values from CODATA (1976) and made extensive use of the tabulated data in the NBS Series 270 and the JANAF (Stull and Prophet 1971) publications. Their selection of these references thus minimizes incompatibility between the thermochemical tables in Robie, Hemingway and Fisher (1978) and the data bank in all published versions of WATEQ. Moreover, the main source of thermodynamic data used for solids in the original version of the data base of WATEQ (Truesdell and Jones 1974) was Robie and Waldbaum (1968). This latter publication is the parent to the more recent bulletin by Robie, Hemingway and Fisher (1978). Both of these bulletins relied on early tabulations by Kelley (1960) and Kelley and King (1961) for relative enthalpy $\left(H_{T}^{0}-H_{298}^{0}\right)^{(a)}$, entropy $\left(S_{T}^{0}\right)$, and heat capacity $\left(C_{p}^{0}\right)$ data for minerals and related substances. Robie and his coworkers have augmented these sources of data with critical literature reviews of publications that contain more recently measured or revised thermodynamic values of heats of formation $\left(\Delta H_{f, T}^{0}\right)$, Gibbs free energy of formation $\left(\Delta G_{f, T}^{0}\right),\left(H_{T}^{0}-H_{298}^{0}\right), S_{T}^{0}$, and $C_{P}^{0}$.

(a) The subscript "298" refers to a standard reference temperature of $298.15 \mathrm{~K}$ $\left(25.0^{\circ} \mathrm{C}\right)$. The superscript " 0 " accompanying thermodynamic symbols refers to a standard reference pressure of $1.0 \mathrm{~atm}$ (1.013 bars). 
The JANAF Thermochemical Tables by Stull and Prophet (1971) and their later supplements (Chase et al. 1974, 1975, 1978) were also considered as a source of thermodynamic data for minerals and other solid phases. These tables were compiled as a task in the National Standard Reference Data System and were administered by the U.S. National Bureau of Standards. Because the JANAF tables were also used in the review and compilation of Robie, Hemingway and Fisher (1978), our tabulation of data from the JANAF tables was a somewhat superfluous act with respect to a comparison of thermodynamic values. However, the importance of these tables by Stull and Prophet (1971) and Chase et al. $(1974,1975,1978)$ should not be understated; the data and accompanying documentation are informative and valuable.

The "standard" thermodynamic data tabulated in the compilations cited above are primarily based on direct calorimetric, solubility, electrochemical and spectroscopic measurements. However, a different approach was taken in the derivation and tabulation of thermochemical data by Helgeson et al. (1978). These latter authors used thermodynamic relations to combine existing or estimated thermodynamic data with mineral-equilibria relations determined from hydrothermal experiments to derive an internally consistent set of thermodynamic values for minerals. Their criteria for these derivations are that the resulting thermodynamic values be compatible with geologic observations and with studies of phase equilibria between minerals. A further difference in approach is that the values derived by Helgeson et al. (1978) were not necessarily referenced back to thermodynamic data from the NBS Series 270 and CODATA publications, especially with respect to data for the aqueous species. Although thermodynamic values from Helgeson et al. (1978) were not selected for the present additions to the data base in WATEQ3, values from Helgeson et al. (1978) were included in the preliminary compilation and were used as an indication that the accepted thermodynamic data were compatible with observed mineral-stability relations.

Sadiq and Lindsay (1979) also completed a literature review, critique, and tabulation of thermodynamic data for minerals, amorphous phases, and aqueous species relevant to the chemistry of soils. Much of the data in Sadiq and Lindsay (1979) for minerals and related solids are referenced to the 
values given in the NBS Series 270 and CODATA tabulations, as well as to publications by $R$. Robie and $B$. Hemingway. Thus, the differences between the values given in Sadiq and Lindsay (1979) and Robie, Hemingway and Fisher (1978) should be relatively minor. Based on the values cited in Sadiq and Lindsay (1979), most of the small differences can probably be attributed to their accepted values for the ancillary thermochemical values used to compute the $\Delta G_{f, 298}^{0}$ values for the solids.

Naumov, Ryzhenko and Khodakovsky (1974) was also used as a potential source of thermodynamic data for minerals and related solid phases. Their tabulation was reviewed for potential references in the Soviet literature that may have been missed in the other thermodynamic tabulations; however, no new references were identified. Although some undocumented criticisms exist with respect to internal inconsistencies of the thermodynamic data tabulated in Naumov, Ryzhenko and Khodakovsky (1974), no obvious inconsistencies were found during this review. Moreover, because Naumov, Ryzhenko and Khodakovsky (1974) reference most of their thermodynamic data for silicate minerals to Kelley (1960) and Kelley and King (1961), their data are often identical with those in Robie and Waldbaum (1968) and Robie, Hemingway and Fisher (1978). 
THERMODYNAMIC DATA SELECTED FOR MINERALS

AND RELATED SOLID PHASES

Values of $\Delta H_{f, 298}^{0}$ based on the elements and of $S_{298}^{0}$ were selected for minerals, related solids, aqueous species, and elements from the references described in the previous section. These values were then used to calculate a set of internally consistent $\Delta G_{f, 298}^{0}$ values for the minerals and solids of interest. Selection of the accepted $\Delta H_{f, 298}^{0}$ and $S_{298}^{0}$ values was based on the recentness and creditability of the published compilations of thermodynamic data and on earlier additions of data to the WATEQ models.

The selected thermodynamic values for the minerals, elements, and related solids and aqueous species, which were used to compute the final values of heats of reaction, $\Delta H_{r, 298}^{0}$, and $\log _{10} \mathrm{~K}_{r, 298}^{0}$, are given in Tables 2, 3, and 4. (a) These tables contain lists of accepted values of $\Delta G_{f, 298}^{0}, \Delta H_{f, 298}^{0}$ (based on the elements), and $S_{298}^{0}$, as well as the sources from which these values were chosen. With four exceptions [data for $\mathrm{Al}(\mathrm{OH})_{4}^{-}$, wollastonite, gehlenite, and akermanite], the sources of data in Tables 2, 3 and 4 are those discussed in the previous section.

Robie, Hemingway and Fisher (1978) was the major source for the accepted data in Tables 2, 3, and 4 . The NBS Series 270 and CODATA publications, however, were also used extensively. If the values tabulated in Robie, Hemingway and Fisher (1978) for a particular solid phase or species are identical to the values given in the NBS Series 270 or CODATA tabulations, the selected data are referenced back to these earlier publications. Values taken from Robie, Hemingway and Fisher (1978), as a main source of thermodynamic data, should maintain internal consistency in the data bank because this compilation relies heavily on the thermodynamic data tabulated in the NBS Series 270 publications and Robie and Waldbaum (1968), as did earlier versions of the WATEQ model.

(a) A sufficient number of digits are given for thermodynamic values throughout this report to ensure their traceability to their quoted sources. For conversion, $1 \mathrm{cal}=4.184$ Joules absolute was used. 
TABLE 2. Accepted Thermodynamic Values for Elements Used for Calculation of Values of $\Delta H_{r}^{O}, 298$ and $L_{0} 10 K_{r}^{O}, 298$. [By convention, $\Delta H_{f}, 298$ and $\Delta G_{f}, 298$ for the elements are equal to zero. "The abbreviations " $c$ " and " $g$ " refer to crystalline and gaseous states, respectively. All entropy values are equal to those in Robie, Hemingway and Fisher (1978), corrected to $1 \mathrm{~atm}$.

\begin{tabular}{|c|c|c|}
\hline Element & $S_{298}^{0}\left(\right.$ cal mol $\left.{ }^{-1} K^{-1}\right)$ & Reference \\
\hline Al (c) & 6.776 & CODATA (1976) \\
\hline $\mathrm{Ca}(\mathrm{c})$ & 9.950 & $\begin{array}{l}\text { Robie, Hemingway and Fisher } \\
\text { (1978) }\end{array}$ \\
\hline$F_{2} \quad(g)$ & 48.443 & CODATA (1976) \\
\hline $\mathrm{Fe} \quad(\mathrm{c})$ & 6.520 & Wagman et al. (1969) \\
\hline $\mathrm{H}_{2} \quad(g)$ & 31.207 & CODATA $(1976)$ \\
\hline$k \quad(c)$ & 15.46 & CODATA $(1976)$ \\
\hline $\operatorname{Mg} \quad(c)$ & 7.811 & $\begin{array}{l}\text { Robie, Hemingway and Fisher } \\
\text { (1978) }\end{array}$ \\
\hline $\mathrm{Na}$ (c) & 12.26 & CODATA $(1976)$ \\
\hline $0_{2} \quad(g)$ & 49.006 & CODATA $(1976)$ \\
\hline $\mathrm{Si}(\mathrm{c})$ & 4.496 & CODATA (1976) \\
\hline
\end{tabular}

Certain thermodynamic values for $\mathrm{Al}_{1}(\mathrm{OH})_{4}^{-}$, wollastonite $\left(\mathrm{CaSiO}_{3}\right)$, åkermanite $\left(\mathrm{Ca}_{2} \mathrm{MgSi}_{2} \mathrm{O}_{7}\right)$, and gehlenite $\left(\mathrm{Ca}_{2} \mathrm{Al}_{2} \mathrm{SiO}_{7}\right)$ were taken from sources other than those described in the previous section. The revised Gibbs free energy of formation for $\mathrm{Al}_{(\mathrm{OH})_{4}^{-}}$was selected from Hemingway, Robie and Kittrick (1978) because it had been recomputed from the new heat of formation for gibbsite $\left[\mathrm{Al}(\mathrm{OH})_{3}\right]$ determined by Hemingway and Robie (1977a) and tabulated in Robie, Hemingway and Fisher (1978). A revised entropy at $298 \mathrm{~K}, \mathrm{~S}_{298}^{0}$, for wollastonite $\left(\mathrm{CaSiO}_{3}\right)$ was taken from the recent study of Krupka et al. (1980). The latter authors calculated a revised entropy of wollastonite based on their new low-temperature heat capacity measurements. Revised values of $\Delta \mathrm{H}_{f, 298}^{0}$ for 
TABLE 3. Accepted Thermodynamic Values for Aqueous Species Used for Calculation of Values of $\Delta \mathrm{H}_{r}^{P}, 298$ and $\log _{10} \mathrm{~K}_{r}^{O}, 298$. [The standard state for an aqueous species is a molality of 1.0. Unless otherwise noted, $\Delta \mathrm{H}_{f}^{\mathrm{O}}, 298$ and $\mathrm{S}_{298} 98$ values are from the same reference. Values noted by asterisk are identical to those in Robie, Hemingway and Fisher (1978) corrected to $1 \mathrm{~atm}$.

\begin{tabular}{|c|c|c|c|c|}
\hline Species & $\Delta H_{f, 298}^{0}$ & $\Delta G_{f, 298}^{O}$ & $S_{298}^{0}$ & Reference \\
\hline & $\left(\mathrm{kcal} \mathrm{\textrm {mol } ^ { - 1 } )}\right.$ & $\left(\mathrm{kcal} \mathrm{mol}^{-1}\right)$ & (cal mol $\mathrm{mo}^{-1}$ ) & \\
\hline $\mathrm{Al}+3$ & -126.9 & -116.9 & -73.61 & $\begin{array}{l}\text { Robie, Hemingway and } \\
\text { Fisher (1978) }\end{array}$ \\
\hline $\mathrm{A} 1(\mathrm{OH})_{4}$ & - & -311.9 & - & $\begin{array}{l}\text { Hemmingway, Robie and } \\
\text { Kittrick (1978) }\end{array}$ \\
\hline $\mathrm{Ca}^{+2}$ & $-129.740 *$ & -132.294 & $-12.69 *$ & $\begin{array}{l}\text { Parker, Wagman and } \\
\text { Evans (1971) }\end{array}$ \\
\hline $\mathrm{CaOH}^{+}$ & - & -171.7 & - & $\begin{array}{l}\text { Parker, Wagman and } \\
\text { Evans (1971) }\end{array}$ \\
\hline $\mathrm{Ca}(\mathrm{OH})_{2}^{0}$ & -239.68 & -207.49 & -17.8 & $\begin{array}{l}\text { Parker, Wagman and } \\
\text { Evans (1971) }\end{array}$ \\
\hline $\mathrm{F}^{-}$ & $-80.151 *$ & -67.34 & $-3.150 *$ & CODATA (1976) \\
\hline $\mathrm{Fe}^{+2}$ & $-21 \cdot 3 \star$ & -18.85 & $-32.9 *$ & Wagman et a1. (1969) \\
\hline $\mathrm{Fe}^{+3}$ & $-11 \cdot 6^{\star}$ & -1.10 & $-75.5 \star$ & Wagman et al. (1969) \\
\hline $\mathrm{K}^{+}$ & $-60.270 \star$ & -67.513 & $24.149 \star$ & CODATA $(1976)$ \\
\hline $\mathrm{Mg}^{+2}$ & $-111.58 *$ & -108.7 & $-33.0 \star$ & $\begin{array}{l}\text { Parker, Wagman and } \\
\text { Evans (1971) }\end{array}$ \\
\hline $\mathrm{Na}^{+}$ & $-57.43 \star$ & -62.59 & $13.96 *$ & CODATA $(1976)$ \\
\hline $\mathrm{OH}^{-}$ & $-54.977 \star$ & -37.604 & $-2.560 \star$ & CODATA $(1976)$ \\
\hline $\mathrm{H}_{4} \mathrm{SiO}_{4}^{\mathrm{O}}$ & $-348.9 \star$ & -312.55 & $43.021 \star$ & $\begin{aligned} \Delta H: & \text { Robie et al. (1978) } \\
\text { S: } & \text { Wagman et al. } \\
& (1968)\end{aligned}$ \\
\hline
\end{tabular}


TABLE 4. Accepted Thermodynamic Values for Several Additional Solids and Water for Calculation of Values of $\Delta \mathrm{HP} 298$ and $\log _{10} \mathrm{KP}$.

[All values are corrected to a $1 \mathrm{~atm}$ pressure; $\ell=$ liquid. Unless otherwise noted, $\Delta \mathrm{H}_{\mathrm{f}}, 298$ and $\mathrm{S}_{298} 98$ values are from the same reference. Values noted by asterisk are identical to those in Robie, Hemingway and Fisher (1978) corrected to $1 \mathrm{~atm}$.

\begin{tabular}{|c|c|c|c|c|c|}
\hline Formula & $\begin{array}{l}\text { Mineral or } \\
\text { Solid Phase }\end{array}$ & $\Delta H_{f, 298}^{0}$ & $\Delta G_{f, 298}^{0}$ & $S_{298}^{0}$ & Reference \\
\hline & & $\left(\mathrm{kcal} \mathrm{mol}^{-1}\right)$ & $\left(\mathrm{kcal} \mathrm{mol}^{-1}\right)$ & (cal mol $\left.{ }^{-1} K^{-1}\right)$ & \\
\hline $\mathrm{CaO}$ & Lime & -151.790 & -144.241 & 9.132 & $\begin{array}{l}\text { Robie, Hemingway and Fisher } \\
\text { (1978) }\end{array}$ \\
\hline $\mathrm{Ca}(\mathrm{OH})_{2}$ & Port landite & $-235.680^{\star}$ & -214.740 & $19.93 \star$ & $\begin{array}{l}\text { Parker, Wagman and Evans } \\
\text { (1971) }\end{array}$ \\
\hline $\mathrm{Fe}_{0.947^{0}}$ & Wustite & $-63.640^{\star}$ & -58.597 & 13.764 & $\begin{array}{c}\Delta \mathrm{H}: \text { Wagman et al. (1969) } \\
\mathrm{S}: \text { Robie, Hemingway and } \\
\text { Fisher (1978) }\end{array}$ \\
\hline $\mathrm{H}_{2} \mathrm{O}(l)$ & Water & $-68.315^{\star}$ & -56.690 & $16.718^{\star}$ & CODATA (1976) \\
\hline $\mathrm{MgO}$ & Periclase & -143.760 & -136.045 & 6.439 & $\begin{array}{l}\text { Robie, Hemingway and Fisher } \\
\text { (1978) }\end{array}$ \\
\hline $\mathrm{FeAl}_{2} \mathrm{O}_{4}$ & Hercynite & $-470.000^{\star}$ & -442.366 & 25.399 & $\begin{array}{c}\Delta \mathrm{H}: \text { Wagman et al. (1969) } \\
\mathrm{S}: \text { Robie, Hemingway and } \\
\text { Fisher (1978) }\end{array}$ \\
\hline $\mathrm{MgAl}_{2} \mathrm{O}_{4}$ & Spinel & -549.551 & -519.705 & 19.271 & $\begin{array}{c}\Delta \mathrm{H}: \text { Robie, Hemingway and } \\
\text { Fisher (1978); } \\
\text { S: Parker, Wagman and } \\
\text { Evans (1971) }\end{array}$ \\
\hline $\mathrm{MgFe}_{2} \mathrm{O}_{4}$ & Magnesio-ferrite & $-341.401^{\star}$ & -314.788 & 29.601 & $\begin{array}{c}\Delta \mathrm{H}: \text { Parker, Wagman and } \\
\text { Evans (1971) } \\
\text { S: Robie, Hemingway and } \\
\text { Fisher (1978) }\end{array}$ \\
\hline $\mathrm{Na}_{3} \mathrm{~A} \mathrm{IF}_{6}$ & Cryolite & -791.000 & -751.676 & 56.991 & $\begin{array}{l}\text { Robie, Hemingway and Fisher } \\
\text { (1978) }\end{array}$ \\
\hline $\mathrm{CaSiO}_{3}$ & Wollastonite & -390.827 & -370.424 & 19.524 & $\begin{array}{c}\Delta \mathrm{H}: \quad \text { Robie, Hemingway and } \\
\text { Fisher (1978); } \\
\text { S: Krupka, Kerrick and } \\
\text { Robie (1980) }\end{array}$ \\
\hline
\end{tabular}


TABLE 4. contd

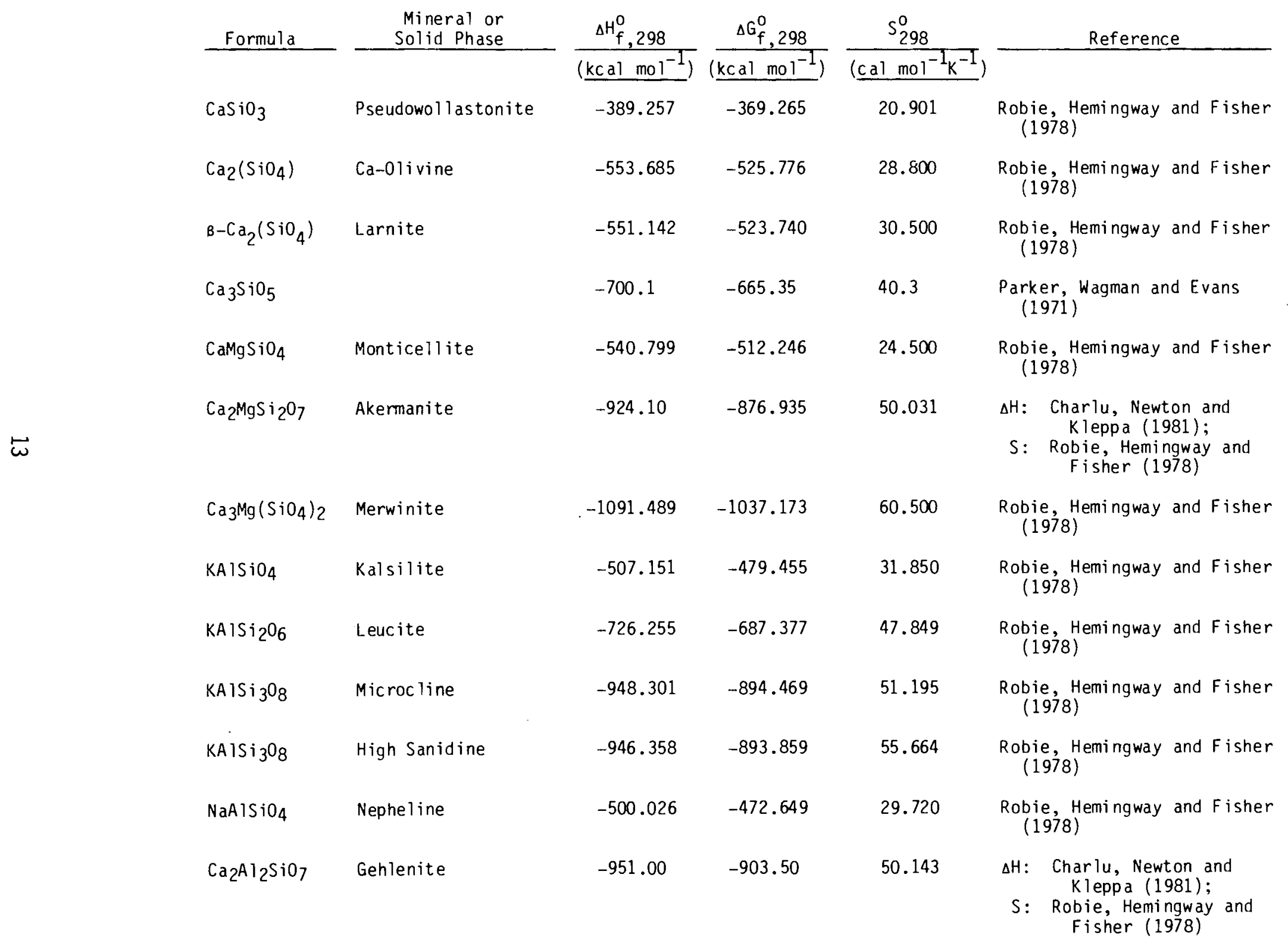


àkermanite and gehlenite were taken from Charlu, Newton and Kleppa (1981). Values of $\Delta H_{f, 970}^{0}$ for these two silicates were determined by Charlu, Newton and Kleppa using high-temperature, molten-oxide solution calorimetry. They then extrapolated these high-temperature values to $298 \mathrm{~K}$ and calculated $\Delta H_{f, 298}^{0}$ values based on the elements using heat $c$ apacity and $\Delta H_{f, 298}^{0}$ data in Robie, Hemingway and $\mathrm{Fisher}(1978)$. Values of $\Delta \mathrm{H}_{\mathrm{f}, 298}^{0}$ for wollastonite and $\mathrm{S}_{298}^{0}$ for àkermanite and gehlenite, however, were selected from Robie, Hemingway and Fisher (1978).

Because of the considerable effort required, a total revision of the data bank for WATEQ3 is not immediately feasible. The use of superceded thermodynamic data to compute $\log _{10} \mathrm{~K}_{r, 298}^{0}$ values simply for the sake of internal consistency is unjustifiable because modeling efforts would then be based on inferior data. Thus, our newly accepted thermodynamic data may be inconsistent with the previously used data for the ancillary species necessary to calculate the $\Delta H_{r, 298}^{0}$ and $\log _{10} K_{r, 298}^{0}$ values for the dissolution reactions of the solid phases. These inconsistencies should be minor, especially when considered in the computation of $\log _{10} \mathrm{~K}_{r, 298}^{0}$ values, because Robie, Hemingway and Fisher (1978) also reference the NBS Series 270 tabulations. The problem of internal consistency may exist particularly in hydrolysis reactions that contain the aqueous species $\mathrm{Al}(\mathrm{OH})_{4}^{-}$. Robie, Hemingway and Fisher (1978) accepted a revised $\Delta G_{f, 298}^{0}$ for $A l(O H)_{4}^{-}$based on the work of Hemingway, Robie and Kittrick (1978). For example, the $\log _{10} \mathrm{~K}_{r, 298}^{0}$ values for the association reaction of $\mathrm{Al}_{(\mathrm{OH})_{4}^{-}}$as now exists in the WATEQ2 data base and as calculated from the data in Tables 3 and 4 are, respectively, -23.0 (Ball, Jenne and Nordstrom 1979, Reaction 82) and -23.35. Because many of the $\log _{10} K_{r, 298}^{0}$ values in WATEQ are based on solubility measurements (e.g., gibbsite), the $\log _{10} K_{r, 298}^{0}$ values will depend on the $\Delta G_{f, 298}^{0}$ values for $A 1(O H)_{4}^{-}$, as well as on ancillary data for $\mathrm{Al}^{+3}, \mathrm{H}_{2} \mathrm{O} \mathrm{OH}^{-}$, and pertinent solid phases. Therefore, although the inconsistencies are expected to be minor, they must be evaluated on a case-by-case basis as time permits.

Two of the new, improved thermodynamic values that Robie, Hemingway and Fisher (1978) have accepted are particularly significant to the WATEQ data base. One revision includes the changes in the $\Delta H_{f, T}^{0}$ and $\Delta G_{f, T}^{0}$ for the 
$\mathrm{Al}^{+3}$ ion, the aluminum-hydroxide minerals (including gibbsite), and several aluminosilicate minerals. These major revisions are based on a new enthalpy of formation of gibbsite $\left[\mathrm{Al}(\mathrm{OH})_{3}\right]$, and an enthalpy correction for a particlesize effect in the heat of solution for $\alpha$-quartz (Hemingway and Robie 1977a). As explained in Robie, Hemingway and Fisher (1978, p. 9), the enthalpy of formation of gibbsite is particularly important because gibbsite is commonly used as the aluminum-bearing phase in a reaction scheme for solution calorimetry of aluminosilicate minerals. Possible discrepancies in the published thermodynamic data for gibbsite were recognized more than a decade ago (Kittrick 1966). The enthalpy of formation, therefore, of a phase derived from such a solution-reaction scheme will depend on the currently accepted values for the enthalpies of formation for the reactants (i.e., gibbsite). Thus, when a new heat of formation is determined for a reference reactant, a1 1 heats of formation derived with that reactant must be recalculated to account for the difference between the new and old values. Revisions resulting from the new $\Delta H_{f, 298}^{0}$ of gibbsite were made to thermodynamic data for aluminosilicates in Hemingway and Robie (1977a); for aqueous $\mathrm{Al}(\mathrm{OH})_{4}^{-}$, diaspore, boehmite and bayerite in Hemingway, Robie and Kittrick (1978); and for the $\mathrm{Al}^{+3}$ ion in Hemingway and Robie (1977b).

The second revision of major importance, which was incorporated in the tabulation of Robie, Hemingway and Fisher (1978), was a correction for particle-size effects in the heat of solution of a-quartz. This correction was applied to some $\Delta H_{f, 298}^{0}$ values of silicate minerals that were determined at the Berkeley Thermodynamics Laboratory of the U.S. Bureau of Mines. The heat of solution of a-quartz was determined experimentally by Hemingway and Robie (1977a) to be greater by $300 \mathrm{cal} \mathrm{mol}^{-1}$ for quartz particles less than $10 \mu \mathrm{m}$, relative to quartz with larger diameters. Hemingway and Robie (1977a) also found that the Berkeley Thermodynamics Laboratory of the U.S. Bureau of Mines utilized a-quartz of less than $10 \mu \mathrm{m}$ in several solution calorimetric studies. Because the enthalpy corrections for this particle-size effect were not realized at the time of their investigations, some of the published $\Delta H_{f, 298}^{0}$ values were based on an inappropriate heat of solution for $\alpha$-quartz. 
Hemingway and Robie (1977a) have reviewed the published data from this group at the U.S. Bureau of Mines and have recalculated the $\Delta H_{f, 298}^{0}$ and $\Delta G_{f, 298}^{0}$ values for several silicate minerals originally computed with the incorrect heat of solution of $\alpha$-quartz.

The reference state for thermodynamic values in Robie, Hemingway and Fisher (1978) is a temperature of $298.15 \mathrm{~K}$ and a pressure of 1 bar $(0.9867 \mathrm{~atm}$, or $10^{5}$ Pascals). Thus, for consistency with older tabulations (i.e., NBS Series 270) and the data base in WATEQ, the values selected from Robie, Hemingway and $F$ isher (1978) must be converted from $P=0.9867$ atm to $a P=$ $1.0 \mathrm{~atm}$ standard state. This conversion, computed from the gas $1 \mathrm{aw}$, decreases the entropy of gaseous elements by a constant $0.026 \mathrm{cal} \mathrm{mol}^{-1} \mathrm{~K}^{-1}$. Values of $\Delta G_{f, 298}^{0}$ from the elements were recomputed for the selected minerals in Tables 2, 3, and 4, based on the entropies of the gaseous elements at 1 atm. The resulting changes to the values of $\Delta G_{f, 298}^{0}$ for these minerals were minor. A factor of $1 \mathrm{cal}=4.1840$ Joules absolute was used to convert the data in Robie, Hemingway and Fisher (1978) to units of calories.

The entropy values $\left(S_{298}^{0}\right)$ tabulated in Robie, Hemingway and Fisher (1978) for aluminosilicate minerals have also been corrected for any configurational entropy terms. These configurational entropies result from Al/Si disorder that is frozen in certain aluminosilicate structures at $0.0 \mathrm{~K}$. In this instance, $S_{0}^{O}(a)$ does not equal zero at $0.0 \mathrm{~K}$ (i.e., for high sanidine, $S_{0}^{0}=4.47 \mathrm{cal} \mathrm{mol}^{-1} \mathrm{~K}^{-1}$ ). The tabulation by Ulbrich and Waldbaum (1976) was used by Robie, Hemingway and Fisher (1978) as a guide for assessing these corrections to the entropy terms.

Tables 2, 3, and 4 also contain our selected thermochemical data for the ancillary components (i.e., elements and aqueous species) necessary to compute values of $\Delta H_{r, 298}^{0}$ and $\log _{10} K_{r, 298}^{0}$ for the hydrolysis reactions. For the aqueous species, the standard state of the selected data is the "hypothetical ideal 1 molal solution," in which the solute has some of the partial molar

(a) The use of "0" as a subscript denotes a temperature of zero Kelvin $\left(-273.15^{\circ} \mathrm{C}\right)$. 
properties of the infinitely dilute solution (Glasstone 1972). The reference state is, in turn, the infinitely dilute solution. Thus, the activity "A" of the solute is defined such that the ratio of this activity to the molality " $m$ " is then unity at a pressure of one atmosphere. This definition (Glasstone 1972) is based on the principle that

$$
\frac{A}{m} \rightarrow 1 \quad \text { as } \quad m \rightarrow 0 \text {. }
$$



SELECTION OF $\Delta G_{f, 298}^{O}$ VALUES FOR LEPIDOCROCITE

Lepidocrocite, $\gamma-\mathrm{Fe} 0(\mathrm{OH})$, is dimorphous with goethite, $\alpha-\mathrm{FeO}(\mathrm{OH})$. Lepidocrocite forms typically from the rapid oxidation of $F e(I I)$ through the intermediate products of green $\mathrm{Fe}(\mathrm{II})$ solution complexes or solid green rusts (Murray 1979). Its formation is generally restricted to $\mathrm{Fe}(\mathrm{II})$ systems, but it may occasionally form from pure Fe(III) systems. The addition of thermodynamic data for lepidocrocite is therefore necessary to competently model solubility controls in waters that may undergo rapid oxidation from low $E^{H}$ conditions. In the compilations described earlier, Sadiq and Lindsay (1979) provide the only tabulation of data for lepidocrocite.

Sadiq and Lindsay (1979) calculated $\Delta G_{f, 298}^{0}$ values for lepidocrocite based on $\log _{10} K_{r, 298}^{0}=-38.7$ (Langmuir 1969) and $\log _{10} K_{r, 298}^{0}=-40.6$ (Schuylenborgh 1973) for the reaction

$$
\gamma-\mathrm{FeO}(\mathrm{OH})+\mathrm{H}_{2} \mathrm{O}=\mathrm{Fe}^{+3}+3 \mathrm{H}^{-}
$$

Based on the above $\log _{10} \mathrm{~K}_{r, 298}^{0}$ from Langmuir (1969), Sadiq and Lindsay (1979) computed a $\Delta G_{f, 298}^{0}=-112.9 \mathrm{kcal} \mathrm{mol}^{-1}$ for lepidocrocite. On the other hand, Langmuir (1969) tabulated $\Delta G_{f, 298}^{0} \leq-169.614 \mathrm{kcal} \mathrm{mol}^{-1}$ for lepidocrocite and $\Delta G_{f, 298}^{0} \geq-115.280$ to $-116.375 \mathrm{kcal} \mathrm{mol}^{-1}$ for goethite, which appears to be a discrepancy with the known stability of lepidocrocite relative to goethite. Lepidocrocite, being dimorphous with goethite $[\alpha-\mathrm{FeO}(\mathrm{OH})]$, is considered less stable than goethite at $25^{\circ} \mathrm{C}$ and 1 atm total pressure (Langmuir 1969; Murray 1979). We have attributed this discrepancy to a possible typographical error by Langmuir, or possibly to the fact that Langmuir (1969) tabulated a minimum $\Delta G_{f, 298}^{0}$ for goethite and a maximum $\Delta G_{f, 298}^{0}$ for lepidocrocite. From the data of Schuylenborgh (1973), Sadiq and Lindsay (1979) calculated $\Delta G_{f, 298}^{0}=-115.50 \mathrm{kcal} \mathrm{mol}^{-1}$ for lepidocrocite.

Gibbs free energies of formation at $298 \mathrm{~K}$ of -112.610 and $-110.018 \mathrm{kcal} \mathrm{mol}^{-1}$ (Table 5) were computed, respectively, from the $\log _{10} K_{r, 298}^{0}$ values of -40.6 (Schuylenborgh 1973) and -38.7 (Langmuir 
TABLE 5. $\Delta G_{f}^{0}, 298$ for Lepidocrocite and $\log _{10} K_{r}^{0}, 298$ for Its Hydrolysis Reaction: $\gamma-\mathrm{FeO}(\mathrm{OH})+3 \mathrm{H}^{+} \stackrel{r}{=} \mathrm{Fe}^{+3}+2 \mathrm{H}_{2} \mathrm{O}$.

\begin{tabular}{llll}
\multicolumn{1}{c}{ Data Source } & $\frac{\Delta G_{f, 298}^{0}}{\frac{\left(k c a l ~ m o l^{-1}\right)}{\log _{10} K_{r}^{0}}}$ & \\
Schuylenborgh (1973) & -112.610 & 1.371 \\
Langmuir (1969) & -110.018 & 3.271
\end{tabular}

1969), using the accepted $\Delta G_{f, 298}^{0}$ values in Tables 2 and 3 . These free energy values differ by $2.9 \mathrm{kcal}$ from the corresponding values computed by Sadiq and Lindsay (1979) as a result of the different values used for $\Delta G_{f, 298}^{0}$ of $\mathrm{Fe}^{+3}$.

A $\Delta G_{f, 298}^{0}$ value of $-112.610 \mathrm{kcal} \mathrm{mol}^{-1}$ was accepted as the best free energy value for lepidocrocite. Although somewhat subjective, this decision was based on the following logic: 1) data of Schuylenborgh (1973) were more recent, and 2) this $\Delta G_{f, 298}^{0}$ was in accord with the "best" value recommended by Sadiq and Lindsay (1979). The $\Delta G_{f, 298}^{0}$ value calculated from the data of Langmuir (1969) will be used as a limit for the "maximum" positive $\Delta G_{f, 298}^{0}$ value for lepidocrocite. 


$\frac{\text { ESTIMATION OF } \Delta G_{f, 298}^{0} \text { FOR IDEAL END-MEMBER NONTRONITE }}{\text { AND HANFORD NONTRONITE }}$

Nontronite, an iron-rich clay, is an end member of the montimorillonite group (smectites) of minerals. In the ideal nontronite structure, the octahedral positions contain $\mathrm{Fe}^{+3}$ and the tetrahedral positions are filled with $\mathrm{Al}^{+3}$ and $\mathrm{Si}^{+4}$ at the atomic ratio of $0.33 \mathrm{Al} / 3.67 \mathrm{Si}$ (Deer, Howie and Zussman 1967). Nontronite is a common alteration product in fractures and vesicles in Columbia River basalts under the Hanford Site in southeast Washington. Thus, to adequately model solubility controls in basalt aquifers, a geochemical model should contain thermodynamic data for nontronite. Because the thermodynamic properties of nontronite have not been determined by calorimetric or solubility measurements, $\Delta G_{f, 298}^{0}$ values for ideal end-member nontronite and a composition that approximates nontronite in the Columbia River basalts were calculated using the estimation method of Mattigod and Sposito (1978).

\section{DESCRIPTION OF ESTIMATION METHODS}

Methods for estimating the Gibbs free energy of formation of clay minerals (Slaughter 1966a, 1966b, 1966c; Tardy and Garrels 1974; Chen 1975; Nriagu 1975; and Mattigod and Sposito 1978) differ greatly in complexity, underlying assumptions, and actual success in predicting Gibbs free energies of formation for minerals whose $\Delta G_{f, 298}^{0}$ values were previously determined by experimental methods. A discussion and comparison of all reported methods are beyond the scope of this document. [See Benson, Carnahan and Che (1980) for a brief review of the different methods for estimating $\Delta G_{f, 298}^{0}$ of layer silicates. Their general criticism, which we also support, centers on the empirical nature of these estimation methods.]

In this study, the approach of Mattigod and Sposito (1978) was used because of: 1) its simplicity, 2) its provision of a Gibbs free energy correction for cation bonding on the exchangeable, interlayer sites, and 3) its success in estimating $\Delta G_{f, 298}^{0}$ for montimorillonite compositions for which $\Delta G_{f, 298}^{0}$ has been determined experimentally. The estimation methods of 
Mattigod and Sposito (1978) and Tardy and Garrels (1974), another commonly used technique, are briefly described. Benson, Carnahan and Che (1980) have criticized the approach of Mattigod and Sposito because it relies on the estimation technique of Chen $(1975)^{(a)}$ to derive a relationship to correct $\Delta G_{f, 298}^{0}$ for cation bonding on the exchangeable, interlayer sites. (b) Calculated $\Delta G_{f, 298}^{0}$ values by Mattigod and Sposito (1978), who used this correction scheme, are in good agreement with data from published solubility studies. However, as pointed out by Benson, Carnahan and Che (1980), the solubility studies for clay minerals may themselves be in error due to kinetic limitations in the experiments. Therefore, the use of Chen's approach does not appear to invalidate the estimation method proposed by Mattigod and Sposito (1978), nor does it decrease the empirical nature of their approach. Based on currently available solubility data for clays, the method of Mattigod and Sposito (1978) appears to give the most reasonable estimates of $\Delta G_{f, 298}^{0}$ for clays.

The estimation method described by Mattigod and Sposito (1978) for smectite clays involves a summation of the Gibbs free energies for hydroxide or oxide and $\mathrm{H}_{2} \mathrm{O}$ components based on the stoichiometry of the clay and a correctional, free energy term for cation bonding in the exchangeable, interlayer sites. This method $\mathrm{c}$ an be described by the equation:

$$
\begin{aligned}
& \Delta G_{f, 298}^{0}(\text { clay })= \\
& \quad \sum n_{i} \Delta G_{f, 298}^{0}\left(r_{i}\right)-\left(\sum n_{i} X_{i}-12\right) \Delta G_{f, 298}^{0}\left(H_{2} 0\right)-|\delta|
\end{aligned}
$$

where

$$
\begin{aligned}
n_{i}= & \text { stoichiometric reaction coefficient of the } i \text { th hydroxide } \\
& \text { or oxide; } \\
x_{i}= & \text { charge on the cation in the } i \text { th hydroxide or oxide; }
\end{aligned}
$$

(a) The $\Delta G_{f, 298}^{0}$-estimation method of Chen (1975) and its limitations are not discussed in our report. They are briefly discussed in Benson, Carnahan and Che (1980) and will be obvious on reading Chen (1975).

(b) For the $\Delta G 9$, 298 estimations for nontronite, these corrections varied between 4 and 10 percent of the final $\Delta G_{f}^{0}, 298$ values. 


$$
\begin{aligned}
\Delta G_{f, 298}^{0}\left(r_{j}\right)= & \text { standard Gibbs free energy of formation for the ith } \\
& \text { hydroxide or oxide in the reaction; } \\
\Delta G_{f, 298}^{0}\left(H_{2} 0\right)= & \text { standard Gibbs free energy of formation for liquid } \mathrm{H}_{2} 0 \\
|\delta|= & \text { absolute value for Gibbs free energy correction based on } \\
& \text { the exchange capacity of the clay, and the ionic radius } \\
& \text { and valence of the cation in the exchangeable, interlayer } \\
& \text { site. }
\end{aligned}
$$

Mattigod and Sposito (1978) present estimation methods based on hydroxide and also on oxide components. The hydroxide-summation method was chosen for our $\Delta G_{f, 298}^{0}$ estimations because the free energy calculations by Mattigod and Sposito, using hydroxide components, are in closer agreement to experimentallydetermined $\Delta G_{f, 298}^{0}$ values for several montmorillonites than their calculations are when using oxide components. The general formula for ideal, end-member nontronite (Deer, Howie and Zussman 1967) is

$$
\mathrm{A}_{0.33} \mathrm{Fe}_{2}^{+3}\left(\mathrm{Al}_{0.33^{\mathrm{Si}}} \mathrm{S}_{3.67}\right) \mathrm{O}_{10}(\mathrm{OH})_{2} \cdot \mathrm{nH}_{2} \mathrm{O}
$$

where $A$ refers to the exchangeable cations $\mathrm{Na}, \mathrm{K}, 0.5 \mathrm{Ca}$, or $0.5 \mathrm{Mg}$. For estimating the free energy of ideal nontronite, the formation reaction from the hydroxides is written as

$$
\begin{aligned}
& 0.33 \mathrm{~A}^{\mathrm{Z}}(\mathrm{OH})_{\mathrm{Z}}+2 \mathrm{Fe}(\mathrm{OH})_{3}+0.33 \mathrm{~A} 7(\mathrm{OH})_{3} \\
& +3.67\left(\mathrm{SiO}_{2} \cdot 2 \mathrm{H}_{2} \mathrm{O}\right)=\mathrm{A}_{0.33} \mathrm{Fe}_{2}^{+3}\left(\mathrm{Al}_{0.33} \mathrm{Si}_{3.67}\right) \mathrm{O}_{10}(\mathrm{OH})_{2} \text {. }
\end{aligned}
$$

Because the oxygen and hydrogen do not balance in the above reaction, a free energy term [i.e., $\left(\Sigma n_{i} x_{i}-12\right) \Delta G_{f, 298}^{0}\left(H_{2} 0\right)$ ] is applied to the estimation to balance the hydroxyl units in the formation reaction. The stoichiometry for the formation reaction from the hydroxides will obviously differ from those for clays with intermediate compositions. Moreover, the water component $\left(\mathrm{nH}_{2} \mathrm{O}\right)$ is not included in this reaction because of its low stability in the clay structure.

The correctional term for the exchangeable cation was calculated by Mattigod and Sposito (1978) from the differences between estimated [using the method of Chen (1975)] and experimentally determined $\Delta G_{f, 298}^{0}$ values as a 
function of the exchange capacity of the clay, and of the radius and valence of the exchangeable cation. These observed trends were then fit to equations by multiple regression techniques. For the hydroxide-summation method, their equation for the correction for exchangeable cations is

$$
\ln _{e}|\delta|=1.9283 C+0.3501 x-0.2819 z+3.5427
$$

where

$C=$ exchange capacity of the clay per formula unit, in equivalents per formula weight;

$X=$ radius of the exchangeable cation, in angstroms $(\AA)(1 \mathrm{~nm}=10 \AA)$;

$Z$ = valence of the exchangeable cation.

The antilog of this value is then subtracted from the free energy summation.

Gibbs free energy of formation values for the $\mathrm{Na}$ and $\mathrm{Ca}$ end-member compositions of nontronite were also estimated with the method of Tardy and Garrels (1974). This method also involves the summation of $\Delta G_{f}^{0}$ values for oxide and hydroxide components whose compositions total to the stoichiometry of the clay or layer silicate. However, the $\Delta G_{f}^{0}$ values used in the estimation method (Tardy and Garrels 1974) are not the standard $\Delta G_{f, 298}^{0}$ values normally tabulated for the separate oxide and hydroxide phases, but are free energy values calculated for these components accounting for structural effects of the layer silicate. The basic assumption of this method is that the "silicated" free energies for the oxide and hydroxide components within the silicate structure are independent of the matrix in which they occur; that is, the crystalstructure effects are of little consequence. Therefore, one can calculate the "silicated" free energies for oxide and hydroxide components from complex layer silicates using their known, standard Gibbs free energies of formation. For example, by solving simultaneous equations, Tardy and Garrels (1974) calculated "silicated" free energies, $\Delta G_{f, s i l}^{O}$, for $\mathrm{SiO}_{2}$, $M g O$ and $M g(O H)_{2}$ from the following equations:

$$
\begin{aligned}
& 2 \Delta G_{f, s i l}^{0}\left(S_{2}\right)+\Delta G_{f, s i l}^{O}(M g O) \\
& \quad+2 \Delta G_{f, s i l}^{O}\left(M g(O H)_{2}\right)=\Delta G_{f, 298}^{0}(\text { chrysotile })
\end{aligned}
$$




$$
\begin{aligned}
& 4 \Delta G_{f, s i\rceil}^{0}\left(S i O_{2}\right)+2 \Delta G_{f, s i\rceil}^{0}(M g 0) \\
& +\Delta G_{f, s i 1}^{O}\left(M g(O H)_{2}\right)=\Delta G_{f, 298}^{O}(\text { talc }) \\
& 3 \Delta G_{f, \text { sil }}^{0}\left(\mathrm{SiO}_{2}\right)+2 \Delta G_{f, \text { sil }}^{0}\left(\mathrm{Mg}(\mathrm{OH})_{2}\right) \\
& =\Delta G_{f, 298}^{0} \text { (sepiolite) } \text {. }
\end{aligned}
$$

Values of $\Delta G_{f, 298}^{0}$ based on the elements for chrysotile, talc and sepiolite were then taken by Tardy and Garrels from published tabulations. Similar equations were written to derive $\Delta G_{f, \text { sil }}^{O}$ for $\mathrm{Na}_{2} \mathrm{O}, \mathrm{K}_{2} \mathrm{O}, \mathrm{CaO}, \mathrm{Al}_{2} \mathrm{O}_{3}$ and $\mathrm{Al}(\mathrm{OH})_{3}$.

Because accurate $\Delta G_{f, 298}^{0}$ values for layer silicates containing ferric iron are lacking, Tardy and Garrels (1974) had to assign a value to $\Delta G_{f, s i l}^{0}$ $\left(\mathrm{Fe}_{2} \mathrm{O}_{3}\right)$. The calculated value of $\Delta \mathrm{G}_{\mathrm{f}}^{\mathrm{O}, \mathrm{sil}}\left(\mathrm{SiO}_{2}\right)$ was identical to the standard $\Delta G_{f, 298}^{0}$ of quartz from which Tardy and Garrels concluded that the energy associated with silication of $\mathrm{SiO}_{2}$ was zero. Because the electronegativity for $\mathrm{Fe}^{+3}$ is simliar to that for $\mathrm{Si}^{+4}$, Tardy and Garrels assumed that the energy of silication was also zero for the silicated $\mathrm{Fe}_{2} \mathrm{O}_{3}$ component. Therefore, they equated the $\Delta G_{f, s i l}^{0}\left(F_{2} O_{3}\right)$ to the standard $\Delta G_{f, 298}^{0}$ of hematite, $\mathrm{Fe}_{2} \mathrm{O}_{3}$.

Tardy and Garrels (1974) also calculated Gibbs free energy values, $\Delta G_{f, \text { ex }}^{0}$, for components in the exchangeable, interlayer sites in the clays. Using published equilibrium constants for exchange reactions, they evaluated the differences between Gibbs free energies for layer silicates as a function of the cations in the interlayer sites. Based on some reaction data for muscovite, Tardy and Garrels then assumed that $\Delta G_{f \text {, ex }}^{0}$ and $\Delta G_{f, s i l}^{0}$ were equal for the $K_{2} O$ component. Values for $\Delta G_{f}^{O}$, ex for the other oxide components in the exchange sites (e.g., $\mathrm{Na}_{2} \mathrm{O}$ ) were calculated by the addition of these free energy differences to the $\Delta G_{f, s i l}^{0}\left(K_{2} 0\right)$.

Tardy and Garrels (1974) normally assigned the magnesium first to the silicated $\mathrm{Mg}(\mathrm{OH})_{2}$ instead of the silicated MgO component for cases of hydrated silicates. Although Tardy and Garrels determined values for $\Delta G_{f, s i l}^{0}\left(H_{2} O\right)$ and $\Delta G_{f, e x}^{0}\left(H_{2} 0\right)$, the hydroxyl units in the layer silicate 
structure are balanced by the addition of sufficient $\mathrm{Mg}(\mathrm{OH})_{2}$ in the $\Delta \mathrm{G}_{\mathrm{f}}^{0}$ summation. Residual magnesium required to balance the $\mathrm{Mg}^{+2}$ content in the clay was added as the silicated Mg0 component.

To estimate the $\Delta G_{f, 298}^{0}$ of a given clay with the procedure of Tardy and Garrels, the formula for the clay is broken down into the appropriate oxide and hydroxide components in the proper stoichiometric proportions. The sum of $\Delta G_{f, s i l}^{0}$ and $\Delta G_{f, \text { ex }}^{0}$ values for these components is then equated to the $\Delta G_{f, 298}^{0}$ for that layer silicate composition.

CALCULATION OF $\Delta G_{f, 298}^{0}$ FOR IDEAL END-MEMBER NONTRONITE

Gibbs free energy of formation from the elements at $298.15 \mathrm{~K}$ were estimated with the method of Mattigod and Sposito (1978) for four end-member compositions of nontronite. These end-member compositions, which differ only in the cations present in the exchangeable sites, include:

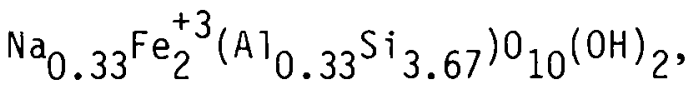

$$
\begin{aligned}
& \mathrm{K}_{0.33} \mathrm{Fe}_{2}^{+3}\left(\mathrm{Al}_{0.33} \mathrm{Si}_{3.67}\right) 0_{10}(\mathrm{OH})_{2} \text {, } \\
& \left(1 / 2 \mathrm{Ca}_{0.33}\right) \mathrm{Fe}_{2}^{+3}\left(\mathrm{Al}_{0.33} \mathrm{Si}_{3.67}\right){ }_{10}(\mathrm{OH})_{2} \text {, } \\
& \left(1 / 2 \mathrm{Mg}_{0.33}\right) \mathrm{Fe}_{2}^{+3}\left(\mathrm{Al}_{0.33} \mathrm{Si}_{3.67}\right) 0_{10}(\mathrm{OH})_{2} \text {. }
\end{aligned}
$$

For comparison, $\Delta G_{f, 298}^{0}$ values were also estimated using the method of Tardy and Garrels (1974) for the end-member compositions of nontronite that have the extreme $\Delta G_{f, 298}^{0}$ values computed by the method of Mattigod and Sposito (1978). Ancillary values of $\Delta G_{f, 298}^{0}$ for $\mathrm{Al}(\mathrm{OH})_{3}, \mathrm{Ca}(\mathrm{OH})_{2}, \mathrm{Fe}(\mathrm{OH})_{3}, \mathrm{KOH}, \mathrm{NaOH}$, and $\mathrm{Mg}(\mathrm{OH})_{2}$ were taken from Robie, Hemingway and $\mathrm{Fisher}$ (1978) and corrected from the 1 bar to 1 atm standard state. The $\Delta G_{f, 298}^{0}$ of solid $\mathrm{SiO}_{2} \cdot 2 \mathrm{H}_{2} \mathrm{O}$ was taken from the NBS Technical Note Series 270-3 (Wagman et al. 1968).

To compute the bond correction, $\delta$, for the free energies of cations in the exchangeable interlayer sites, values of 0.080 and $0.120 \mathrm{eq} / 100 \mathrm{~g}$ were used as extreme values for the exchange capacities of montmorillonite clays (Bohn, McNeal and O'Connor 1979). These values were multiplied by the formula weight of each composition to convert units of equivalents per mole (or per 
"formula weight"). Values used for ionic radii, which were taken from Evans (1966), include $0.95,1.33,0.99$, and $0.65 \AA$ for $\mathrm{Na}^{+}, \mathrm{K}^{+}, \mathrm{Ca}^{+2}$, and $\mathrm{Mg}^{+2}$, respectively.

The $\Delta G_{f, 298}^{0}$ values estimated for the four end-member nontronite compositions at the two different exchange capacities are given in Table 6 . The estimated free energy values range from $-1073.1 \mathrm{kcal} / \mathrm{mol}$ for Na-nontronite at the low exchange capacity to $-1089.0 \mathrm{kcal} / \mathrm{mol}$ for Ca-nontronite at the high exchange capacity. The difference of $15.9 \mathrm{kcal}$ between these extreme values constitutes only 1.5 percent of each $\Delta G_{f, 298}^{0}$ value. The differences between these estimated values are not significant with respect to the estimation scheme when compared to the absolute magnitude of the free energy values, but are significant in the final $\log _{10} K_{r, 298}^{0}$ values. For comparison, $\Delta G_{f, 298}^{0}$ values estimated by Wolery (1978) for these same nontronite compositions are also listed in Table 6 . Although Wolery used a different set of thermodynamic data and the estimation procedure of Tardy and Garrels (1974), no significant differences exist between the two sets of estimated $\Delta G_{f, 298}^{0}$ values.

In order to compare estimation methods, Gibbs free energies for the ideal $\mathrm{Na}-$ and $\mathrm{Ca}$-nontronites were also estimated using the procedure described by Tardy and Garrels (1974). These nontronite compositions were selected because they possessed the minimum and maximum $\Delta G_{f, 298}^{0}$ values as calculated by the method of Mattigod and Sposito (1978). Ali standard, tabulated $\Delta G_{f, 298}^{0}$ values were taken from Robie, Hemingway and Fisher (1978). The silicated Gibbs free energy, $\Delta \mathrm{G}_{\mathrm{f}, \mathrm{Sil}}^{\mathrm{O}}$, for the $\mathrm{SiO}_{2}$ and $\mathrm{Fe}_{2} \mathrm{O}_{3}$ components were set equal to the standard $\Delta G_{f, 298}{ }^{\prime}$ values of $\alpha$-quartz and hematite, respectively (Tardy and Garrels 1974). The Gibbs free energies of quartz, kaolinite $\left[\mathrm{Al}_{2} \mathrm{Si}_{2} \mathrm{O}_{5}(\mathrm{OH})_{4}\right]$, and pyrophyllite $\left[\mathrm{Al}_{2} \mathrm{Si}_{4} \mathrm{O}_{10}(\mathrm{OH})_{2}\right]$ were used to evaluate by simultaneous equations the $\Delta G_{f}^{O} \mathrm{Sil}_{1}$ of the $\mathrm{Al}_{2} \mathrm{O}_{3}, \mathrm{H}_{2} \mathrm{O}$, and $\mathrm{Al}(\mathrm{OH})_{3}$ components. Similarly, the $\Delta G_{f, 298}^{O}$ of muscovite, $\mathrm{KAl}_{2}\left(\mathrm{AlSi}_{3} \mathrm{O}_{10}\right)(\mathrm{OH})_{2}$, was used to calculate the $\Delta G_{f, s i l}^{0}$ of the $K_{2} 0$ component. With the same assumption made by Tardy and Garrels (1974), the $\Delta G_{f, s i l}^{0}$ of $K_{2} 0$ was equated to $\Delta G_{f}^{0}$, ex of $K_{2} 0$ in the interlayer sites of the clay. Then, using the $\Delta G_{f}^{0}$, ex of $K_{2} 0$ and the free energy differences tabulated in Tardy and Garrels (1974, Table 3), $\Delta G_{f, e x}^{0}$ values were calculated for $\mathrm{Na}_{2} \mathrm{O}$ and $\mathrm{CaO}$ in the interlayer sites. These computed values of $\Delta G_{f, s i l}^{0}$ and $\Delta G_{f, e x}^{0}$ are given in Table 7. Because there is 
TABLE 6. Estimated $\Delta G_{f}^{0} 298$ Values for Ideal End-Member Nontronite and for a Nontronite Composition Characteristic of Altered Columbia Plateau Basalts at the Hanford Site.

\begin{tabular}{|c|c|c|c|}
\hline \multirow{2}{*}{\multicolumn{2}{|c|}{$\begin{array}{c}\begin{array}{c}\text { Method of } \\
\text { Mattigod and Sposito (1978) }\end{array} \\
\begin{array}{c}\text { Low-Exchange(a) } \\
\text { Capacity }\end{array}\end{array}$}} & $\begin{array}{l}\text { thod of } \\
\text { ardy and } \\
\text { rels (1974) }\end{array}$ & \multirow[t]{3}{*}{$\begin{array}{l}\text { Estimations in } \\
\text { Wolery (1978) }\end{array}$} \\
\hline & & \multirow[b]{2}{*}{$\left.\mathrm{mol}^{-1}\right)$} & \\
\hline & $\Delta G_{f, 298}^{0}(\mathrm{kcal}$ & & \\
\hline-1073.1 & -1079.6 & \multirow[t]{2}{*}{-1079.6} & -1078.271 \\
\hline-1075.6 & -1083.2 & & -1080.356 \\
\hline-1084.0 & -1089.0 & \multirow[t]{3}{*}{-1080.8} & -1079.492 \\
\hline-1080.0 & -1084.3 & & -1075.647 \\
\hline-1097.0 & -1107.2 & & \\
\hline
\end{tabular}

(a) Low- and high-exchange capacities used for estimations were 0.080 and $0.120 \mathrm{eq} / 100 \mathrm{~g}$, respectively.

(b) Compositions of nontronite given in Table 1.

(c) Composition of Hanford nontronite given in text (p. 35). 
TABLE 7. Calculated Values for Silicated Free Energies $\left(\Delta G_{f}^{0}\right.$, sil) for Estimation of $\Delta G$ Q 298 of Ideal End-Member Nontronite Using the Method of Tardy and Garrels (1974).

\begin{tabular}{|c|c|c|}
\hline Component & $\Delta G_{f, s i l}^{0}$ & $\Delta G_{f, s i 1, e^{(a)}}^{0}$ \\
\hline & & $\left.\mathrm{mol}^{-1}\right)$ \\
\hline $\mathrm{SiO}_{2}$ & -204.67 & \\
\hline $\mathrm{Fe}_{2} \mathrm{O}_{3}$ & -177.52 & \\
\hline $\mathrm{Al}_{2} \mathrm{O}_{3}$ & -381.09 & \\
\hline $\mathrm{Al}(\mathrm{OH})_{3}$ & -278.78 & \\
\hline $\mathrm{H}_{2} \mathrm{O}$ & -58.82 & \\
\hline $\mathrm{K}_{2} \mathrm{O}$ & -188.272 & \\
\hline $\mathrm{CaO}_{\mathrm{ex}}^{(\mathrm{a})}$ & & -183.07 \\
\hline $\mathrm{Na}_{2} \mathrm{O}_{\mathrm{ex}}^{(\mathrm{a})}$ & & -175.67 \\
\hline
\end{tabular}

(a) Subscript "ex" refers to component on the exchangeable, interlayer sites in the clay.

no $\mathrm{Mg}$ in the "ideal" nontronite, $\mathrm{Mg}(\mathrm{OH})_{2}$ could not be used to balance hydroxyl units in the nontronite formula (Tardy and Garrels 1974). To balance the hydroxyl units, the $\Delta G_{f, 298}^{0}$ of $N a$ - and $\mathrm{Ca}$-nontronite were estimated with $\Delta G_{f, \text { sil }}^{0}$ of either $A 1(0 H)_{3}$ or $H_{2} 0$. The resulting $\Delta G_{f, 298}^{0}$ values were identical when the calculations were based on either $A l(O H)_{3}$ or $H_{2} O$. The $\Delta G_{f, 298}^{O}$ values estimated with the method of Tardy and Garrels (1974) for "ideal" Na- and Ca-nontronite are given in Table 6. They do not differ from the Gibbs free energy values estimated with the procedure of Mattigod and Sposito (1978) and those of Wolery (1978).

ESTIMATION OF COMPOSITION AND $\Delta G_{f, 298}^{0}$ FOR HANFORD NONTRONITE

A composition, based on electron probe data, was estimated for the nontronite that exists in fractures and vesicles in Columbia River basalts under the Hanford Site in southeast Washington. Benson and Teague (1979) published extensive tables of clay compositions determined by electron probe 
analyses of minerals in Hanford basalts. Because these were chemical analyses of "spot-locations" in mineral grains or aggregates, Benson and Teague could not complete an X-ray diffraction identification for each analyzed grain. Therefore, some subjective criteria had to be used to select a particular oxide analysis from all the clay analyses reported by Benson and Teague (1979). Ames (1980) has identified nontronite by X-ray diffraction in basalt core samples from the Hanford Reservation. In describing the common occurrence of nontronite throughout Columbia River basalts, Ames (1980, p. 155) reports that the nontronite usually contains 25 to 40 wt\% ferric iron and the interlayer sites are dominated by calcium, some sodium, and little potassium. In the ideal nontronite structure, the octahedral positions contain $\mathrm{Fe}^{+3}$ and the tetrahedral positions are filled with $\mathrm{Al}^{+3}$ and $\mathrm{Si}^{+4}$ at the atomic ratio of $0.33 \mathrm{Al} / 3.67 \mathrm{Si}$ (Deer, Howie and Zussman 1967).

Therefore, the following criteria were used for selecting a clay composition from Benson and Teague (1979) that approximates the composition of a Hanford nontronite:

1. analysis should contain little or no $\mathrm{K}_{2} \mathrm{O}$ and $\mathrm{MgO}$,

2. analysis should contain 25 to $40 \mathrm{wt} \%$ ferric iron,

3. analysis should result in an atomic ratio of approximately $0.33 \mathrm{Al} / 3.67 \mathrm{Si}$.

Because ferric and ferrous iron cannot be differentiated by an electron probe analysis, Benson and Teague (1979) calculated their total iron contents in the oxide compositions as $\mathrm{Fe}_{2} \mathrm{O}_{3}$. For our calculations, we assumed that these $\mathrm{Fe}_{2} \mathrm{O}_{3}$ values equal the total ferric iron in the clay. Based on these criteria, the analysis labeled Sample DC6 4220, $1286 \mathrm{~m}$, Analysis A, and Number 26-31 was selected from Benson and Teague (1979, p. 62) to represent a nontronite in alteréd Columbia Plateau basalt. This analysis includes $51.88 \pm$ 1.52 wt $\% \mathrm{SiO}_{2}, 3.74 \pm 0.08 \mathrm{wt} \% \mathrm{Al}_{2} \mathrm{O}_{3}, 32.07 \pm 0.81 \mathrm{wt} \% \mathrm{Fe}_{2} \mathrm{O}_{3}, 1.74 \pm$ 0.13 wt $\% \mathrm{MgO}, 1.10 \pm 0.06 \mathrm{wt} \% \mathrm{CaO}, 1.10 \pm 0.42 \mathrm{wt} \% \mathrm{Na}_{2} 0,0.11 \pm 0.03$ wt $\%$ $\mathrm{K}_{2} \mathrm{O}$, and $8.26 \mathrm{wt} \% \mathrm{H}_{2} \mathrm{O}$. This composition is similar to the analyses for nontronite from Garfield and Colfax (Whitman County), Washington, reported in Deer, Howie and Zussman (1967), with the exception of the $\mathrm{SiO}_{2}$ content, 
which is significantly higher in the analysis of Benson and Teague (1979). Using this oxide analysis, the following structural formula was calculated with the procedure described by Ames (1980):

$\left(\mathrm{Na}_{0.16} \frac{1}{2} \mathrm{Ca}_{0.16} \frac{1}{2} \mathrm{Mg}_{0.06} \mathrm{~K}_{0.01}\right)\left(\mathrm{Fe}_{1.75^{+3} \mathrm{Mg}_{0.16^{\mathrm{Al}}} 0.09}\right)\left(\mathrm{Al}_{0.23} \mathrm{Si}_{3.77}\right) 0_{10}(\mathrm{OH})_{2} \cdot$

A $\Delta G_{f, 298}^{0}$ value was calculated for this composition of nontronite with the method of Mattigod and Sposito (1978). This estimated $\Delta G_{f, 298}^{0}$, listed in Table 6 , is more negative by 1.5 to $3.2 \%$ from the $\Delta G_{f, 298}^{0}$ values determined for the ideal end-member nontronites. Because the $\Delta G_{f, 298}^{0}$ of the $\mathrm{SiO}_{2} \cdot 2 \mathrm{H}_{2} \mathrm{O}$ component constitutes about $75 \%$ of the total estimated $\Delta G_{f, 298}^{0}$, the free energy differences between ideal and "Hanford" nontronite are considered insignificant because of the uncertainty assigned to the $\mathrm{SiO}_{2}$ analysis. 
$\because$ 
CALCULATION OF $\Delta_{r, 298}^{0}$ AND LOG ${ }_{10} K_{r, 298}^{0}$ OF THE HYDROLYSIS REACTIONS

The hydrolysis reactions for the newly added minerals were determined in accordance with the same criteria for format and reaction species as described in Ball, Nordstrom and Jenne (1980). Heats of reaction were computed for these reactions based on the relation

$$
\Delta H_{r, 298}^{0}=\sum \Delta H_{f, 298}^{0} \text { (products) }-\sum \Delta H_{f, 298}^{0} \text { (reactants). }
$$

Values of $\log _{10} K_{r, 298}^{0}$ (equilibrium constant of reaction at $298.15 \mathrm{~K}$ ) were calculated from the relation

$$
\log _{10} K_{r, 298}^{0}=-\Delta G_{r, 298}^{0} /(2.30258 \times R \times T),
$$

where

$$
\begin{aligned}
\Delta G_{r, 298}^{0} & =\sum \Delta G_{f, 298}^{0} \text { (products) }-\sum \Delta G_{f, 298}^{0} \text { (reactants) } \\
T & =298.15 \mathrm{~K}, \\
R & =1.9872 \mathrm{cal} \mathrm{mol} l^{-1} \mathrm{~K}^{-1}, \text { gas constant. }
\end{aligned}
$$

The hydrolysis reactions and the values of $\Delta H_{r, 298}^{0}$ and $\log _{10} K_{r, 298}^{0}$, calculated from the ancillary thermodynamic data in Tables 2, 3, and 4, are given in Table 8, except for lepidocrocite and nontronite (discussed previously).

Computed values of $\Delta H_{r, 298}^{0}$ and $\log _{10} K_{r, 298}^{0}$ for microcline and high sanidine, which are two potassium-feldspar polymorphs, have been added to the WATEQ3 data base. Similar data for the hydrolysis reaction of adularia [reaction 39 in Truesde 11 and Jones (1974)] have been deleted from the WATEQ3 data base, because there is some question concerning the usage of the term "adularia." With respect to Al/Si order, microcline and high sanidine, respectively, are the most ordered and most disordered forms of potassium feldspars. The term "adularia" is commonly used for a variety of orthoclase (which is also a potassium feldspar polymorph) that has a distinct morphological habit and is commonly found in hydrothermal veins. The Al/Si disorder and thermal 
TABLE 8. Hydrolysis Reactions and Computed Values of $\Delta H_{r, 298}^{0}$ and $\log _{10} K_{r, 298}^{0}$.

\begin{tabular}{|c|c|c|c|c|}
\hline \multicolumn{2}{|c|}{ Solid Phase } & Reaction & $\Delta H_{r, 298}^{0}(k c a l)$ & $\log _{10} K_{r, 298}^{0}$ \\
\hline & $\begin{array}{l}\text { Ca0, } \\
\text { Lime }\end{array}$ & $\mathrm{CaO}+2 \mathrm{H}^{+}=\mathrm{Ca}^{+2}+\mathrm{H}_{2} \mathrm{O}$ & -46.265 & +32.797 \\
\hline & $\begin{array}{l}\mathrm{Ca}(\mathrm{OH})_{2} \\
\text { Port landite }\end{array}$ & $\mathrm{Ca}(\mathrm{OH})_{2}+2 \mathrm{H}^{+}=\mathrm{Ca}^{+2}+2 \mathrm{H}_{2} \mathrm{O}$ & -30.690 & +22.675 \\
\hline & $\begin{array}{l}\mathrm{Fe}_{0.947^{0}} \\
\text { Wüstite }\end{array}$ & 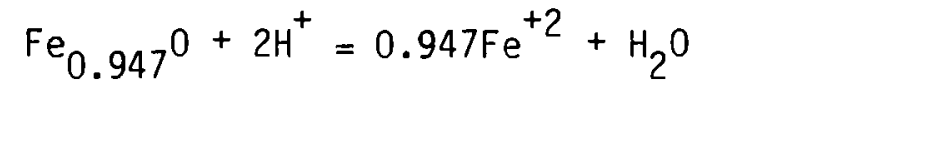 & -24.846 & +11.687 \\
\hline$\omega$ & $\begin{array}{l}\text { Mg0, } \\
\text { Periclase }\end{array}$ & $\mathrm{MgO}+2 \mathrm{H}^{+}=\mathrm{Mg}^{+2}+\mathrm{H}_{2} \mathrm{O}$ & -36.135 & +21.510 \\
\hline & $\begin{array}{l}\mathrm{FeAl}_{2} \mathrm{O}_{4} \\
\text { Hercynite }\end{array}$ & $\mathrm{FeAl}_{2} \mathrm{O}_{4}+4 \mathrm{H}_{2} \mathrm{O}=\mathrm{Fe}^{+2}+2 \mathrm{Al}(\mathrm{OH})_{4}^{-}$ & $--(a)$ & -19.407 \\
\hline & $\begin{array}{l}\mathrm{MgAl}_{2} \mathrm{O}_{4} \\
\text { Spinel }\end{array}$ & $\mathrm{MgAl}_{2} \mathrm{O}_{4}+4 \mathrm{H}_{2} \mathrm{O}=\mathrm{Mg}^{+2}+2 \mathrm{Al}(\mathrm{OH})_{4}^{-}$ & $\ldots(a)$ & -10.236 \\
\hline & $\begin{array}{l}\mathrm{MgFe}_{2} \mathrm{O}_{4} \text {, } \\
\text { Magnesio-ferrite }\end{array}$ & $\mathrm{MgFe}_{2} \mathrm{O}_{4}+8 \mathrm{H}^{+}=\mathrm{Mg}^{+2}+2 \mathrm{Fe}^{+3}+4 \mathrm{H}_{2} \mathrm{O}$ & -66.639 & +16.765 \\
\hline & $\begin{array}{l}\mathrm{Na}_{3} \mathrm{AlF}_{6} \\
\text { Cryolite }\end{array}$ & $\mathrm{Na}_{3} \mathrm{AlF}_{6}+4 \mathrm{H}_{2} \mathrm{O}=\mathrm{Al}(\mathrm{OH})_{4}^{-}+3 \mathrm{Na}^{+}+6 \mathrm{~F}^{-}+4 \mathrm{H}^{+}$ & $-{ }_{-}^{(a)}$ & -54.775 \\
\hline
\end{tabular}


TABLE 8. (contd)

\begin{tabular}{|c|c|c|c|}
\hline Solid Phase & Reaction & $\Delta H_{r, 298}^{0}(\mathrm{kcal})$ & $\log _{10} K_{r, 298}^{0}$ \\
\hline $\begin{array}{l}\mathrm{CaSiO}_{3}, \\
\text { Woll astonite }\end{array}$ & $\mathrm{CaSiO}_{3}+\mathrm{H}_{2} \mathrm{O}+2 \mathrm{H}^{+}=\mathrm{H}_{4} \mathrm{SiO}_{4}^{\mathrm{O}}+\mathrm{Ca}^{+2}$ & -19.498 & +12.996 \\
\hline $\begin{array}{l}\mathrm{CaSiO}_{3} \text {, Pseudo- } \\
\text { wollastonite }\end{array}$ & $\mathrm{CaSiO}_{3}+\mathrm{H}_{2} \mathrm{O}+2 \mathrm{H}^{+}=\mathrm{H}_{4} \mathrm{SiO}_{4}^{\mathrm{O}}+\mathrm{Ca}^{+2}$ & -21.068 & +13.846 \\
\hline $\begin{array}{l}\mathrm{Ca}_{2}\left(\mathrm{SiO}_{4}\right) \\
\mathrm{Ca}-01 \text { ivine }\end{array}$ & $\mathrm{Ca}_{2}\left(\mathrm{SiO}_{4}\right)+4 \mathrm{H}^{+}=\mathrm{H}_{4} \mathrm{SiO}_{4}^{\mathrm{O}}+2 \mathrm{Ca}^{+2}$ & -54.695 & +37.649 \\
\hline $\begin{array}{l}\mathrm{B}-\mathrm{Ca}_{2}\left(\mathrm{SiO}_{4}\right) \\
\text { Larnite }\end{array}$ & $\mathrm{B}-\mathrm{Ca}_{2}\left(\mathrm{SiO}_{4}\right)+4 \mathrm{H}^{+}=\mathrm{H}_{4} \mathrm{SiO}_{4}^{\mathrm{O}}+2 \mathrm{Ca}^{+2}$ & -57.238 & +39.141 \\
\hline $\mathrm{Ca}_{3} \mathrm{SiO}_{5}$ & $\mathrm{Ca}_{3} \mathrm{SiO}_{5}+6 \mathrm{H}^{+}=\mathrm{H}_{4} \mathrm{SiO}_{4}^{0}+3 \mathrm{Ca}^{+2}+\mathrm{H}_{2} \mathrm{O}$ & -106.335 & +73.867 \\
\hline $\mathrm{CaMgSiO}_{4}$, & $\mathrm{CaMgSiO}_{4}+4 \mathrm{H}^{+}=\mathrm{H}_{4} \mathrm{SiO}_{4}^{\mathrm{O}}+\mathrm{Ca}^{+2}+\mathrm{Mg}^{+2}$ & -49.421 & +30.272 \\
\hline \multicolumn{4}{|l|}{ Monticellite } \\
\hline 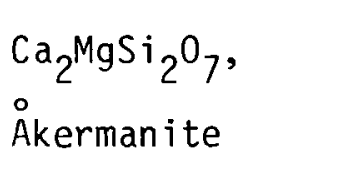 & $\mathrm{Ca}_{2} \mathrm{MgSi}_{2} \mathrm{O}_{7}+\mathrm{H}_{2} \mathrm{O}+6 \mathrm{H}^{+}=2 \mathrm{H}_{4} \mathrm{SiO}_{4}^{\mathrm{O}}+2 \mathrm{Ca}^{+2}+\mathrm{Mg}^{+2}$ & -76.445 & +47.472 \\
\hline $\mathrm{Ca}_{3} \mathrm{Mg}\left(\mathrm{SiO}_{4}\right)_{2}$, & $\mathrm{Ca}_{3} \mathrm{Mg}\left(\mathrm{SiO}_{4}\right){ }_{2}+8 \mathrm{H}^{+}=2 \mathrm{H}_{4} \mathrm{SiO}_{4}^{0}+\mathrm{Mg}^{+2}+3 \mathrm{Ca}^{+2}$ & -107.111 & +68.543 \\
\hline Merwinite & & & \\
\hline
\end{tabular}


TABLE 8. (contd)

\begin{tabular}{|c|c|c|c|}
\hline Solid Phase & Reaction & $\Delta H_{r, 298}^{0}(k c a l)$ & $\log _{10} K_{r, 298}^{0}$ \\
\hline $\mathrm{KAlSiO}_{4}$ & $\mathrm{KAlSiO}_{4}+4 \mathrm{H}_{2} \mathrm{O}=\mathrm{H}_{4} \mathrm{SiO}_{4}^{0}+\mathrm{Al}(\mathrm{OH})_{4}^{-}+\mathrm{K}^{+}$ & $-{ }^{(a)}$ & -10.447 \\
\hline \multicolumn{4}{|l|}{ Kalsilite } \\
\hline $\mathrm{KAISi}_{2} \mathrm{O}_{6}$, & $\mathrm{KAlSi}_{2} \mathrm{O}_{6}+6 \mathrm{H}_{2} \mathrm{O}=2 \mathrm{H}_{4} \mathrm{SiO}_{4}^{\circ}+\mathrm{Al}(\mathrm{OH})_{4}^{-}+\mathrm{K}^{+}$ & $--(a)$ & -16.862 \\
\hline \multicolumn{4}{|l|}{ Leucite } \\
\hline $\mathrm{KAISi}_{3} \mathrm{O}_{8}$ & $\mathrm{KAlSi}_{3} \mathrm{O}_{8}+8 \mathrm{H}_{2} \mathrm{O}=3 \mathrm{H}_{4} \mathrm{SiO}_{4}^{\mathrm{O}}+\mathrm{Al}(\mathrm{OH})_{4}^{-}+\mathrm{K}^{+}$ & $-(a)$ & -22.669 \\
\hline \multicolumn{4}{|l|}{ Microcline } \\
\hline $\mathrm{KAISi}_{3}{ }^{0} 8$ & $\mathrm{KAlSi}_{3} \mathrm{O}_{8}+8 \mathrm{H}_{2} \mathrm{O}=3 \mathrm{H}_{4} \mathrm{SiO}_{4}^{\mathrm{O}}+\mathrm{Al}(\mathrm{OH})_{4}^{-}+\mathrm{K}^{+}$ & $-{ }_{--}(a)$ & -22.223 \\
\hline \multicolumn{4}{|l|}{ High Sanidine } \\
\hline $\mathrm{NaAlSiO}_{4}$ & $\mathrm{NaAlSiO}_{4}+4 \mathrm{H}_{2} \mathrm{O}=\mathrm{H}_{4} \mathrm{SiO}_{4}^{0}+\mathrm{Al}(\mathrm{OH})_{4}^{-}+\mathrm{Na}^{+}$ & $--(a)$ & -9.067 \\
\hline \multicolumn{4}{|l|}{ Nepheline } \\
\hline $\mathrm{Ca}_{2} \mathrm{Al}_{2} \mathrm{SiO}_{7}$, & $\mathrm{Ca}_{2} \mathrm{Al}_{2} \mathrm{SiO}_{7}+5 \mathrm{H}_{2} \mathrm{O}+2 \mathrm{H}^{+}=\mathrm{H}_{4} \mathrm{SiO}_{4}^{\mathrm{O}}+2 \mathrm{Al}(\mathrm{OH})_{4}^{-}+2 \mathrm{Ca}^{+2}$ & $-(a)$ & +10.253 \\
\hline
\end{tabular}

Gehlenite

(a) No $\Delta \mathrm{H}_{\mathrm{f}, 298}^{\mathrm{O}}$ value for $\mathrm{Al}(\mathrm{OH})_{4}^{-}$ 
stability of orthoclase are intermediate to those of microcline and high sanidine (Ribbe 1975). However, according to Bambauer and Laves (1960), adularia may in some cases be structurally classified as sanidine, orthoclase or microcline. The thermodynamic values for adularia in the WATEQ data base were originally taken from Robie and Waldbaum (1968) who computed $\Delta H_{f, 298}^{0}$ and $\Delta G_{f, 298}^{0}$ for adularia from data in Garrels and Christ (1965). Data for adularia or orthoclase, however, are absent in the more recent compilation by Robie, Hemingway and $\mathrm{F}$ isher (1978). Moreover, the removal of adularia from the WATEQ3 data base will not limit geochemical modeling efforts because the $\log _{10} K_{r, 298}^{0}$ value added for microcline and high sanidine are almost identical to the deleted value for adularia.

Calculated values of $\log _{10} k_{r, 298}^{0}$ for the hydrolysis reaction of lepidocrocite are given in Table 5. The value calculated from the data of Schuylenborgh (1973) was selected as our "best" value for lepidocrocite. The $\log _{10} K_{r, 298}^{0}$ value calculated from the data for lepidocrocite in Langmuir (1969) and the ancillary thermodynamic data in Table 3 will be placed in the WATEQ data base as a "maximum" value for lepidocrocite. Both $\log _{10} \mathrm{~K}_{r, 298}^{0}$ values in Table 5 are more positive than the $\log _{10} k_{r, 298}^{0}$ for goethite used in the WATEQ data base, and therefore represent the proper stability order between lepidocrocite and goethite.

The $\Delta G_{f, 298}^{0}$ values in Table 6 , estimated by the procedure of Mattigod and Sposito (1978), were used to compute $\log _{10} K_{r, 298}^{0}$ for the hydrolysis reactions of ideal $\mathrm{Na}-, \mathrm{K}-, \mathrm{Ca}-$, and Mg-nontronites. Ancillary Gibbs free energy data for $\mathrm{Ca}^{+2}, \mathrm{Fe}^{+3}, \mathrm{~K}^{+}, \mathrm{Mg}^{+2}, \mathrm{Na}^{+}, \mathrm{H}_{2} \mathrm{O}, \mathrm{Al}(\mathrm{OH})_{4}^{-}$, and $\mathrm{H}_{4} \mathrm{SiO}_{4}^{\circ}$ were taken from Tables 3 and 4 of our "accepted" thermodynamic data. $\log _{10} K_{r, 298}^{0}$ values were calculated using the equations described in an earlier section of this report.

The hydrolysis reactions and the $\log _{10} k_{r, 298}^{0}$ values for the four nontronite compositions are given in Table $9 . \log _{10} K_{r}^{0}, 298$ values for each nontronite composition were computed with both $\Delta G_{f, 298}^{O}$ values that are based on the two extreme exchange $c$ apacities for smectite clays. Both $\log _{10} K_{r, 298}^{0}$ values will be incorporated into the WATEQ data base until 
TABLE 9. Hydrolysis Reactions and Computed $\log 10 \mathrm{~K} P$. 298 Values for Ideal End-Member Nontronite. Minimum and Maximum Log $10 \mathrm{~K}_{r}^{0}, 298$ Values Calculated from the Low- and High-Exchange Capacities Used in the Free Energy Estimations.

Na-nontronite

$$
\begin{aligned}
& \mathrm{Na}_{0.33} \mathrm{Fe}_{2}^{+3}\left(\mathrm{Al}_{0.33} \mathrm{Si}_{3.67}\right) \mathrm{O}_{10}(\mathrm{OH})_{2}+6 \mathrm{H}^{+}+4 \mathrm{H}_{2} \mathrm{O}= \\
& 2 \mathrm{Fe}^{+3}+0.33 \mathrm{Na}+0.33 \mathrm{Al}(\mathrm{OH})_{4}^{-}+3.67 \mathrm{H}_{4} \mathrm{SiO}_{4}^{\circ} \\
& \text { Minimum } \log _{10} K_{r, 298}^{0}=-19.806 \\
& \text { Maximum } \log _{10} K_{r, 298}^{0}=-24.570
\end{aligned}
$$

K-nontronite

$$
\begin{aligned}
& \mathrm{K}_{0.33} \mathrm{Fe}_{2}^{+3}\left(\mathrm{Al}_{0.33} \mathrm{Si}_{3.67}\right) \mathrm{O}_{10}(\mathrm{OH})_{2}+6 \mathrm{H}^{+}+4 \mathrm{H}_{2} \mathrm{O}= \\
& 2 \mathrm{Fe}^{+3}+0.33 \mathrm{~K}^{+}+0.33 \mathrm{Al}(\mathrm{OH})_{4}^{-}+3.67 \mathrm{H}_{4} \mathrm{SiO}_{4}^{\mathrm{O}}
\end{aligned}
$$

Minimum $\log _{10} K_{r, 298}^{0}=-20.447$

Max imum $\log _{10} K_{r, 298}^{0}=-26.018$

Ca-nontronite

$$
\begin{aligned}
& \left(1 / 2 \mathrm{Ca}_{0.33} \mathrm{Fe}_{2}^{+3}\left(\mathrm{Al}_{0.33} \mathrm{Si}_{3.67}\right) 0_{10}(\mathrm{OH})_{2}+6 \mathrm{H}^{+}+4 \mathrm{H}_{2} \mathrm{O}=\right. \\
& \left.2 \mathrm{Fe}^{+3}+0.167 \mathrm{Ca}^{+2}+0.33 \mathrm{Al}(\mathrm{OH})_{4}^{-}\right)+3.67 \mathrm{H}_{4} \mathrm{SiO}_{4}^{0} \\
& \text { Minimum } \log _{10} \mathrm{~K}_{r, 298}^{0}=-26.741 \\
& \text { Maximum } \log _{10} \mathrm{~K}_{\mathrm{r}, 298}^{0}=-30.406
\end{aligned}
$$

Mg-nontronite

$$
\begin{aligned}
& \left(1 / 2 \mathrm{Mg}_{0.33}\right) \mathrm{Fe}_{2}^{+3}\left(\mathrm{Al}_{0.33} \mathrm{Si}_{3.67}\right) \mathrm{O}_{10}(\mathrm{OH})_{2}+6 \mathrm{H}^{+}+4 \mathrm{H}_{2} \mathrm{O}= \\
& 2 \mathrm{Fe}^{+3}+0.167 \mathrm{Mg}^{+2}+0.33 \mathrm{Al}(\mathrm{OH})_{4}^{-}+3.67 \mathrm{H}_{4} \mathrm{SiO}_{4}^{\circ} \\
& \text { Minimum } \log _{10} \mathrm{~K}_{r, 298}^{0}=-26.697 \\
& \text { Maximum } \log _{10} \mathrm{~K}_{r, 298}^{\mathrm{O}}=-29.849
\end{aligned}
$$

a suitable method is identified to select the proper $\Delta G_{f, 298}^{0}$ or to ascertain a limit of uncertainty for each $\Delta G_{f, 298}^{0}$ value. Assignment of an uncertainty to each $\Delta G_{f, 298}^{0}$ will be difficult because each free energy value for nontronite is itself an "estimation." However, because each estimated $\Delta G_{f, 298}^{0}$ value is 
computed from thermodynamic data with known uncertainties, to carry these uncertainties into the calculation of $\Delta G_{f, 298}^{0}$ and $\log _{10} K_{r, 298}^{0}$ should be possible. Secondly, the two extreme exchange capacities, which are for the complete spectrum of smectite compositions, may overestimate the proper limits of exchange capacity for nontronite compositions. For example, using the exchange capacities of 0.080 and $0.120 \mathrm{eq} / 100 \mathrm{~g}$, the exchange bond $(\delta)$ corrections of 12.79 and $17.75 \mathrm{kcal} \mathrm{mol}^{-1}$, respectively, were calculated for Ca-nontronite. Therefore, overestimation of the exchange capacity of nontronite will increase the differences in the $\Delta G_{f, 298}^{0}$ and $\log _{10} K_{r, 298}^{0}$ values. 


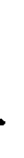




\section{REFERENCES}

Ames, L. L. 1980. Hanford Basalt Flow Mineralogy. PNL-2847, Pacific Northwest Laboratory, Richland, Washington.

Ball, J. W., E. A. Jenne and D. K. Nordstrom. 1979. "WATEQ2 - A Computerized Chemical Model for Trace and Major Element Speciation and Mineral Equilibria of Natural Waters." In Chemical Modeling in Aqueous Systems - Speciation, Sorption, Solubility, and Kinetics: Amer. Chem. Soc. Symposium Series 93, ed. E. A. Jenne, pp. 815-835, Washington, D.C.

Bal1, J. W., E. A. Jenne and M. W. Cantre11. 1981. "WATEQ3 - A Geochemical Model with Uranium Added." U.S. Geol. Survey, Open File Report 81-1183, Menlo Park, Cal ifornia.

Ball, J. W., D. K. Nordstrom and E. A. Jenne. 1980. "Additional and Revised Thermochemical Data and Computer Code for WATEQ2 - A Computerized Chemical Model for Trace and Major Element Speciation and Mineral Equilibria of Natural Waters" U.S. Geol. Survey, Water-Resources Investigations 78-116, Menlo Park, California.

Bambauer, H. U., and F. Laves. 1960. "Zum Adularproblem. I. Adular vom Lamel lenbau, Variation von Optik und Gitterkonstanten und ihre genetische Deutung." Schweiz. Mineral. Petrogr. Mett., 40:177-205.

Benson, L. V. and L. S. Teague. 1979. A Study of Rock-Water-Nuc lear Waste Interactions in the Pasco Basin, Washington. LBL-9677, Lawrence Berkeley Laboratory, Berkeley, California.

Benson, L. V., C. L. Carnahan and M. Che. 1980. A Study of Rock-Water-Nuclear Waste Interactions in the Pasco Basin, Washington. LBL-9677 $2 / 2$, Lawrence Berkeley Laboratory, Berkeley, California.

Bohn, H.I., B. I. McNeal and G. A. O'Connor. 1979. Soil Chemistry. John Wiley and Sons, New York.

Charlu, T. V., R. C. Newton and 0. J. Kleppa. 1981. "Thermochemistry of Synthetic $\mathrm{Ca}_{2} \mathrm{Al}_{2} \mathrm{SiO}_{7}$ (Gehlenite) - $\mathrm{Ca}_{2} \mathrm{MgSi}{ }_{2} \mathrm{O}_{7}$ (Akermanite)

Melilites." Geochim. Cosmo. Acta., 45:1609-1617.

Chase, M. W., J. L. Curnutt, A. T. Hu, H. Prophet, A. N. Syverud and L. C. Walker. 1974. "JANAF Thermochemical Tables, 1974 Supplement." Jour. Phys. Chem. Ref. Data, 3:311-480.

Chase, M. W., J. L. Curnutt, H. Prophet. R. A. McDonald and A. N. Syvrud. 1975. "JANAF Thermochemical Tables, 1975 Supplement." Jour. Phys. Chem. Ref. Data, 4:1-175.

Chase, M. W., Jr., J. L. Curnutt, R. A. McDonald and A. N. Syverud. 1978. "JANAF Thermochemical Tables, 1978 Supplement." Jour. Phys. Chem. Ref. Data, 7:793-940. 
Chen, C.-H. 1975. "A Method of Estimation of Standard Free Energies of Formation of Silicate Minerals at 298.15 K." Amer. Jour. Sci., 275:801-817.

CODATA Task Group. 1976. "CODATA Recommended Key Values for Thermodynamics, 1975." Jour. Chem. Thermodynamics, 8:603-605.

Deer, W. A., R. A. Howie, and J. Zussman. 1967. Rock-Forming Minerals. Volume 3: Sheet Silicates. Longmans, Green and Co. Ltd., London.

Evans, R. C., 1966. An Introduction to Crystal Chemistry. Cambridge University Press.

Fleischer, M. 1980. Glossary of Mineral Species. 1980 Edition and Supplements, Mineralogical Record, Tucson, Arizona.

Garrels, R. M., and C. L. Christ. 1965. Solutions, Minerals, and Equilibria. Harper and Row, New York.

Glasstone, S. 1972. Thermodynamics for Chemists. 14th ed. Robert E. Krieger, New York.

Gross, S. 1977. "The Mineralogy of the Haturium Formation, Israel." Geol. Surv. Israel Bull. No. 70.

Helgeson, H. C., J. M. Delany, H. W. Nesbitt and D. K. Bird. 1978. "Summary and Critique of the Thermodynamic Properties of Rock-Forming Minerals." Amer. Jour. Science, 278-A.

Hemingway, B. S., and R. A. Robie. 1977a. "Enthalpies of Formation of Low Albite $\left(\mathrm{NaAlSi}_{3} \mathrm{O}_{8}\right)$, Gibbsite $\left(\mathrm{Al}(\mathrm{OH})_{3}\right)$, and $\mathrm{NaAlO}_{2}$; Revised Values for $\Delta H Q, 298$ and $\triangle G Q, 298$ of Some Aluminosilicate Minerals." Jour. Res. U.S. Geol. Survey, 5:413-429.

Hemingway, B. S., and R. A. Robie. 1977b. "The Entropy and Gibbs Free Energy of Formation of the Aluminum Ion." Geochim. Cosmo. Acta., 41:1402-1404.

Hemingway, B. S., R. A. Robie and J. A. Kittrick. 1978. "Revised Values for the Gibbs Free Energy of Formation of $\left[\mathrm{Al}(\mathrm{OH})_{4} \mathrm{aq}\right]$, Diaspore, Boehmite and Bayerite at 298.15 K and 1 bar, the Thermodynamic Properties of Kaolinite to $800 \mathrm{~K}$ and 1 bar, and the Heats of Solution of Several Gibbsite Samples." Geochim. Cosmo. Acta., 42:1533-1543.

Kelley, K. K. 1960. "Contributions to the Data on Theoretical Metallurgy. XIII. High-Temperature Heat-Capacity, and Entropy Data for the Elements and Inorganic Compounds." U.S. Bur. Mines Bul1. 584, U.S. Government Printing office, Washington, D.C.

Kelley, K. K., and E. G. King. 1961. "Contributions to the Data on Theoretical Metallurgy. IXV. Entropies of the Elements and Inorganic Compounds." U.S. Bur. Mines Bul1. 592, U.S. Government Printing Office, Washington, D.C. 
Kittrick, J. A. 1966. "The Free Energy of Formation of Gibbsite and $\mathrm{Al}(\mathrm{OH}) \overline{4}$ from Solubility Measurements." Soil Sci. Soc. Proc., $30: 595-598$.

Krupka, K. M., D. M. Kerrick and R. A. Robie. 1980. "Heat Capacities from 5 to $1000 \mathrm{~K}$ for Natural Diopside, Wollastonite, Orthenstatite." EOS, Amer. Geophy. Union, 61:409 (Abstract).

Langmuir, D. 1969. "The Gibbs Free Energies of Substances in the System $\mathrm{Fe}-\mathrm{O}_{2}-\mathrm{H}_{2} \mathrm{O}-\mathrm{CO}_{2}$ at $25^{\circ} \mathrm{C}$." U.S. Geol. Surv. Prof. Paper 650-B, p. B180-B184.

Mattigod, S. V., and G. Sposito. 1978. "Improved Method for Estimating the Standard Free Energies of Formation $\left(\Delta G_{f}^{0}, 298.15\right)$ of Smectites." Geochim. Cosmo. Acta, 42:1753-1762.

Murray, J. W. 1979. "Iron 0xides." In Marine Minerals, ed. R. G. Burns, Min. Soc. Amer. Short Course Notes, 6:47-98, Washington, D.C.

Naumov, G. B., B. N. Ryzhenko and I. L. Khodakovsky. 1974. Handbook of Thermodynamic Data. U.S. Geological Survey WRD-74-001, translation, NTIS-PB-226 722/AS, National Technical Information Service, Springfield, Virginia.

Nriagu, J. 0. 1975. "Thermochemical Approximations for Clay Minerals." Amer. Mineral., 60:834-839.

Parker, V. B., D. D. Wagman and W. H. Evans. 1971. "Selected Values of Chemical Thermodynamic Properties. Tables for the Alkaline Earth Elements (elements 92 Through 97 in the Standard Order of Arrangement)." U.S. Nat1. Bur. Standards Tech. Note 270-6, U.S. Government Printing Office, Washington, D.C.

Parker, V. B., D. D. Wagman and D. Garvin. 1976. "Selected Thermochemical Data Compatible with the CODATA Recommendations." Nat1. Bureau Standards, PB-250 845, U.S. Government Printing Office, Washington, D.C.

Plummer, L. N., B. F. Jones and A. H. Truesdell. 1976. "WATEQF - A Fortran IV Version of WATEQ, A Computer Program for Calculating Chemical Equilibrium of Natural Waters." U.S. Geol. Survey, Water-Resources Investigations 76-13, Reston, Virginia.

Ribbe, P. H. 1975. "The Chemistry, Structure and Nomenclature of Feldspars." In Feldspar Mineralogy, ed. P. H. Ribbe, Min. Soc. Amer. Short Course Notes, 2:R1-R52, Washington, D.C.

Robie, R. A., and D. R. Waldbaum. 1968. "Thermodynamic Properties of Minerals and Related Substances at $298.15^{\circ} \mathrm{K}\left(25.0^{\circ} \mathrm{C}\right)$ and One Atmosphere (1.013 bars) Pressure and at Higher Temperatures." U.S. Geol. Survey Bul1. 1259, U.S. Government Printing Office, Washington, D.C. 
Robie, R. A., B. S. Hemingway and J. R. Fisher. 1978. "Thermodynamic Properties of Minerals and Related Substances at $298.15 \mathrm{~K}$ and 1 bar $\left(10^{5}\right.$ Pascals) Pressure and at Higher Temperatures." U.S. Geol. Survey Bull. 1452 , reprinted with corrections 1979, U.S. Government Printing Office, Washington, D.C.

Rossini, F. D., D. R. Wagman, W. H. Evans, S. Levine and I. Jaffe. 1952. "Selected Values of Chemical Thermodynamic Properties." U.S. Nat1. Bur. Standards Circ. 500, U.S. Government Printing Office, Washington, D.C.

Sadiq, M., and W. Lindsay. 1979. "Selection of Standard Free Energies of Formation for Use in Soil Chemistry." Colorado State Univ. Experimental Station Tech. Bull. 134, Ft. Collins, Colorado.

Schuylenborgh, J. V. 1973. "Sesquioxide Formation and Transformation. 'Pseudolog and Gley." Trans. Comm. V., VI Intern. Soc. Soil Sci. 93-102.

Slaughter, M. 1966a. "Chemical Binding in Silicate Minerals. Part I. Model for Determining Crystal-Chemical Properties." Geochim. Cosmo. Acta, $30: 299-313$.

Slaughter, M. 1966b. "Chemical Binding in Silicate Minerals. Part II. Computational Methods and Approximations for the Binding Energy of Complex Silicates." Geochim. Cosmo Acta, 30:315-322.

Slaughter, M. 1966c. "Chemical Binding in Silicate Minerals. Part III. Application of Energy Calculations to the Prediction of Silicate Mineral Stability." Geochim. Cosmo. Acta, 30:323-339.

Stul1, D. R., and H. Prophet. 1971. "JANAF Thermochemical Tables: National Reference Data Series." V. 37, U.S. Bureau of Standards, U.S. Government Printing Office, Washington, D.C.

Tardy, Y. and R. M. Garrels. 1974. "A Method of Estimating the Gibbs Energies of Formation of Layer Silicates." Geochim. Cosmo. Acta, 38:1101-1116.

Truesde11, A. H., and B. F. Jones. 1974. "WATEQ, a Computer Program for Calculating Chemical Equilibria of Natural Waters." Jour. Res. U.S. Geol. Survey, 2:233-248.

Ulbrich, H. H., and D. R. Waldbaum. 1976. "Structural and Other Contribution to the Third-Law Entropies of Silicates." Geochim. Cosmo. Acta, 40:1-24.

Wagman, D. D., W. H. Evans, V. B. Parker, I. Halow, S. M. Bailey and R. H. Schumm. 1968. "Selected Values of Chemical Thermodynamic Properties. Tables for the First Thirty-Four Elements in the Standard Order Arrangement." U.S. Nat1. Bur. Standards Tech. Note 270-3, U.S. Government Printing Office, Washington, D.C. 
Wagman, D. D., W. H. Evans, V. B. Parker, I. Halow, S. M. Bailey and R. H. Schumm. 1969. "Selected Values of Chemical Thermodynamic Properties. Tables for Elements 35 through 53 in the Standard Order Arrangement." U.S. Nat1. Bur. Standards Tech. Note 270-4, U.S. Government Printing office, Washington, D.C.

Wagman, D. D., W. H. Evans, V. B. Parker and R. H. Schumm. 1976. "Chemical Thermodynamic Properties of Compounds of Sodium, Potassium, and Rubidium: An Interim Tabulation of Selected Values." NTIS No. PB-254 460, (NBSIR 76-1034), National Technical Information Service, Springfield, Virginia.

Wagman, D. D., W. H. Evans, V. B. Parker, R. H. Schumm and R. L. Nutall. 1981. Selected Values of Chemical Thermodynamic Properties. Compounds of Uranium, Protactinium, Thorium, Actinium, and the Alkali Metals: U.S. Natl. Bur. Standards Tech. Note 270-8, U.S. Government Printing Office, Washington, D.C.

Westal1, J. C., J. L. Zachary and F. M. M. Morel. 1976. MINEQL, A Computer Program for the Calculation of Chemical Equilibrium Composition of Aqueous Systems. Tech. Note 18, Dept. Civil Eng., Massachusetts Institute of Technology, Cambridge, Massachusetts.

Wolery, T. J. 1978. Some Chemical Aspects of Hydrothermal Processes at MidOceanic Ridges--A Theoretical Study. I. Basalt-Sea Water Reaction and Chemical cycling Between the Oceanic crust and the Oceans. II. Calculation of Chemical Equilibrium Between Aqueous Solutions and Minerals. Ph.D. Dissertation, Northwestern University, Evanston, Illinois. 


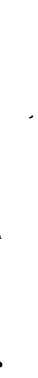


APPENDIX A

EXAMPLE OF LOG $10 \mathrm{~K}_{r, 298}^{0}$ CALCULATIONS 
EXAMPLE OF LOG ${ }_{10} K_{r, 298}^{0}$ CALCULATIONS

The development and upgrading of the thermodynamic data bank for a geochemical model must be approached in an arduous fashion to maintain the best possible internal consistency with the previously compiled data. This appendix shows an example of the calculations necessary to generate internally consistent $\Delta G_{f, 298}^{0}$ and $\log _{10} K_{r, 298}^{0}$ values based on previously selected "best" values for $\mathrm{S}_{298}^{\mathrm{O}}$ and $\Delta \mathrm{H}_{\mathrm{f}, 298}^{\mathrm{O}}$ for the constituent elements, the ancillary components in the reaction, and the solid phase subject of the $\log _{10} \mathrm{~K}_{r}^{0}$ value. For the example, the $\log _{10} \mathrm{~K}_{r, 298}^{0}$ and $\Delta \mathrm{H}_{r, 298}^{0}$ values for the hydroylsis reaction for wollastonite $\left(\mathrm{CaSiO}_{3}\right)$ are calculated from the ancillary thermodynamic data. The hydroylsis reactions will be written in terms of $\mathrm{H}^{+}$and/or $\mathrm{H}_{2} \mathrm{O}$ as required by the WATEQ3 code (Ball, Nordstrom and Jenne 1980).

\section{STEP 1}

"Best" values should be first accepted for $S_{298}^{0}$ and $\Delta H_{f, 298}^{0}$ for the constituent elements, the ancillary components in the reaction, and the subject solid phase. These values should be the same as those previously used to calculate $\Delta H_{r, 298}^{0}$ and $\log _{10} \mathrm{~K}_{r, 298}^{0}$ for the existing phases in the geochemical model. For these calculations, the NBS Series 270 and CODATA were the primary sources for the $S_{298}^{0}$ and $\Delta H_{f, 298}^{0}$ values, because they were used in past data supplements to the WATEQ data base. Obviously, as a data bank evolves over several years, the selection of "best" values may change. The earlier $\Delta H_{r, 298}^{0}$ and $\log _{10} K_{r, 298}^{0}$ values should be revised, as time permits, with respect to the more recent thermodynamic data. The "best" thermodynamic values necessary for this calculation are given in Table A.1; these data were listed earlier in Tables 2, 3, and 4 . 
STEP 2

Values of $\Delta G_{f, 298}^{0}$ for $\mathrm{H}_{2} \mathrm{O}, \mathrm{H}_{4} \mathrm{SiO}_{4}^{0}$ (aqueous), $\mathrm{Ca}^{+2}$ and wollastonite are next calculated from the data in Table A.1. They are computed from the fundamental thermodynamic relationship,

$$
\Delta G_{f, 298}^{0}=\Delta H_{f, 298}^{0}-298.15 \Delta S_{f, 298}^{0}
$$

where $\Delta S_{f, 298}^{0}$ is the entropy difference between that component and its constituent elements. The calculation of these $\Delta G_{f, 298}^{0}$ values are shown on the following pages, and the resulting values should be compared to those in Tables 3 and 4.

$\Delta G_{f, 298}^{0}$ for $H_{2} 0$

$$
\begin{aligned}
& \mathrm{H}_{2}+\frac{1}{2} \mathrm{O}_{2}=\mathrm{H}_{2} \mathrm{O} \\
& \Delta \mathrm{G}_{\mathrm{f}, 298}^{\mathrm{O}}\left(\mathrm{H}_{2} \mathrm{O}\right)=\Delta \mathrm{H}_{\mathrm{f}, 298}^{\mathrm{O}}\left(\mathrm{H}_{2} \mathrm{O}\right)- \\
& \quad 298.15\left[\mathrm{~S}_{298}^{\mathrm{O}}\left(\mathrm{H}_{2} \mathrm{O}\right)-\mathrm{S}_{298}^{\mathrm{O}}\left(\mathrm{H}_{2}\right)-0.5 \mathrm{~S}_{298}^{0}\left(\mathrm{O}_{2}\right)\right] \\
& \Delta \mathrm{G}_{\mathrm{f}, 298}^{0}\left(\mathrm{H}_{2} \mathrm{O}\right)=-68,315-298.15[16.718-31.207-0.5(49.006)] \\
& \Delta \mathrm{G}_{\mathrm{f}, 298}^{0}\left(\mathrm{H}_{2} \mathrm{O}\right)=-56,690 \mathrm{cal} \mathrm{mol}^{-1}
\end{aligned}
$$

$\Delta G_{f, 298}^{0}$ for $\mathrm{H}_{2} \mathrm{SiO}_{4}^{\mathrm{O}}$ (aqueous)

$$
\begin{aligned}
& 2 \mathrm{H}_{2}+\mathrm{Si}+2 \mathrm{O}_{2}=\mathrm{H}_{4} \mathrm{SiO}_{4}^{\circ} \\
& \Delta G_{f, 298}^{O}\left(H_{4} \mathrm{SiO}_{4}^{O}\right)=\Delta H_{f, 298}^{O}\left(H_{4} \mathrm{SiO}_{4}^{O}\right)- \\
& 298.15\left[\mathrm{~S}_{298}^{\mathrm{O}}\left(\mathrm{H}_{4} \mathrm{SiO}_{4}^{0}\right)-2 \mathrm{~S}_{298}^{0}\left(\mathrm{H}_{2}\right)-\mathrm{S}_{298}^{0}(\mathrm{Si})-2 \mathrm{~S}_{298}^{0}\left(\mathrm{O}_{2}\right)\right] \\
& \Delta G_{f, 298}^{0}\left(H_{4} \mathrm{SiO}_{4}^{0}\right)=-348,900- \\
& 298.15[43.0-2(31.207)-4.496-2(49.006)] \\
& \Delta G_{f, 298}^{0}\left(\mathrm{H}_{4} \mathrm{SiO}_{4}^{0}\right)=-312,550 \mathrm{cal} \mathrm{mol}^{-1}
\end{aligned}
$$


TABLE A.1. Thermodynamic Values Necessary to Calculate Internally Consistent $\Delta \mathrm{H}_{\mathrm{O}}^{\mathrm{O}} 298$ and $\log _{10} \mathrm{~K}_{r}^{0}, 298$ Values for Wỏllastonite.

\begin{tabular}{|c|c|c|}
\hline Phase or Species & $\Delta H_{f, 298}^{0}$ & $S_{298}^{0}$ \\
\hline & $\left(\mathrm{kcal} \mathrm{mol}^{-1}\right)$ & $\left(\mathrm{cal} \mathrm{mol}^{-1} \mathrm{~K}^{-1}\right.$ \\
\hline $\mathrm{Ca}$ & $0^{(a)}$ & 9.950 \\
\hline $\mathrm{e}^{-}$(electron) $)^{(b)}$ & 0 & 15.6035 \\
\hline $\mathrm{H}_{2}$ & 0 & 31.207 \\
\hline $\mathrm{H}^{+}$ & 0 & 0 \\
\hline $0_{2}$ & 0 & 49.006 \\
\hline $\mathrm{Si}$ & 0 & 4.496 \\
\hline $\mathrm{Ca}^{+2}$ & -129.740 & -12.69 \\
\hline $\mathrm{H}_{2} \mathrm{O}$ & -68.315 & 16.718 \\
\hline $\mathrm{H}_{2} \mathrm{SiO}_{4}^{\circ}$ (Aqueous) & -348.9 & 43.0 \\
\hline Wollastonite & -390.827 & 19.524 \\
\hline
\end{tabular}

(a) The $\Delta H_{f, 298}^{0}$ of the elements in their reference state are zero by convention.

(b) The entropy of the electron $\left(e^{-}\right)$is calculated from the formation reaction $0.5 \mathrm{H}_{2}=\mathrm{H}^{+}+\mathrm{e}^{-}$. Therefore, the entropy of the electron is equal to $0.5 \mathrm{~S}_{298}$ of $\mathrm{H}_{2}$.

$$
\begin{aligned}
& \frac{\Delta G_{f, 298}^{0} \text { for } \mathrm{Ca}^{+2}}{\mathrm{Ca}=\mathrm{Ca}^{+2}+2 \mathrm{e}^{-}} \\
& \Delta \mathrm{G}_{\mathrm{f}, 298}^{0}\left(\mathrm{Ca}^{+2}\right)=\Delta \mathrm{H}_{\mathrm{f}, 298}^{0}\left(\mathrm{Ca}^{+2}\right)-298.15\left[\mathrm{~S}_{298}^{0}\left(\mathrm{Ca}^{+2}\right)+2 \mathrm{~S}_{298}^{0}(\mathrm{e}-)-\right. \\
& \left.\quad \mathrm{S}_{298}^{0}(\mathrm{Ca})\right] \\
& \Delta \mathrm{G}_{\mathrm{f}, 298}^{0}\left(\mathrm{Ca}^{+2}\right)=-129,740-298.15[-12.69+2(15.6035)-9.950] \\
& \Delta \mathrm{G}_{\mathrm{f}, 298}^{0}\left(\mathrm{Ca}^{+2}\right)=-132,294 \mathrm{Cal} \mathrm{mol}^{-1}
\end{aligned}
$$


$\Delta G_{f, 298}^{0}$ for Wollastonite (wol), $\mathrm{CaSiO}_{3}$

$$
\begin{aligned}
& \mathrm{Ca}+\mathrm{Si}+\frac{3}{2} \mathrm{O}_{2}=\mathrm{CaSiO}_{3} \\
& \Delta G_{f, 298}^{0}(\text { wol })=\Delta H_{f, 298}^{0}(\text { wol })- \\
& 298.15\left[S_{298}^{0}(\text { wol })-S_{298}^{0}(\mathrm{Ca})-S_{298}^{0}(\mathrm{Si})-1.5 \mathrm{~S}_{298}^{0}\left(0_{2}\right)\right] \\
& \Delta G_{f, 298}^{0}(\text { wol })=-390,827-298.15[19.524-9.950-4.496-1.5(49.006)] \\
& \Delta G_{f, 298}^{0}(\text { wol })=-370,424 \mathrm{cal} \mathrm{mol}^{-1}
\end{aligned}
$$

STEP 3

These $\Delta G_{f}^{0} 298$ values and the $\Delta H_{f, 298}^{0}$ values in Table $A .1$ are then used to compute the $\Delta G_{r, 298}^{0}$ and $\Delta H_{r, 298}^{0}$, respectively, for the dissolution reaction for wollastonite as listed in Table 8. The $\Delta G_{r, 298}^{0}$ value can then be used to calculate the $\log _{10} \mathrm{~K}_{r, 298}^{0}$ for the same dissolution reaction.

Wollastonite (Wol)

$$
\begin{aligned}
& \mathrm{CaSiO}_{3}+\mathrm{H}_{2} \mathrm{O}+2 \mathrm{H}^{+}=\mathrm{H}_{4} \mathrm{SiO}_{4}^{\mathrm{O}}+\mathrm{Ca}^{+2} \\
& \Delta G_{r, 298}^{0}=\Delta G_{f, 298}^{0}\left(H_{4} \mathrm{SiO}_{4}^{0}\right)+\Delta G_{f, 298}^{0}\left(\mathrm{Ca}^{+2}\right)-\Delta G_{f, 298}^{0}\left(W_{01}\right) \\
& -\Delta G_{f, 298}^{0}\left(H_{2} 0\right)-2 \Delta G_{f, 298}^{0}\left(H^{+}\right) \\
& \Delta G_{r, 298}^{0}=(-312,550)+(-132,294)-(-370,424)-(-56,690)-2(0) \\
& \Delta G_{r, 298}^{0}=-17,784 \mathrm{cal} \mathrm{mol}^{-1} \\
& \log _{10} K_{r, 298}^{0}=-\left(-17,730 \mathrm{cal}^{-1} \mathrm{~mol}\right) / \\
& \left(2.30258 \times 1.9872 \mathrm{cal} \mathrm{mol}^{-1} \mathrm{~K}^{-1} \times 298.15 \mathrm{~K}\right) \\
& \log _{10} K_{r, 298}^{0}=+12.996
\end{aligned}
$$


By analogy to the calculation of $\Delta G_{f, 298}^{0}$,

$$
\Delta H_{r, 298}^{o}=-19,498 \mathrm{cal} \mathrm{mol}^{-1}
$$

These calculated $\log _{10} \mathrm{~K}_{r, 298}^{0}$ and $\Delta \mathrm{H}_{r, 298}^{0}$ values are identical to those listed in Table 8.

The $\log _{10} K_{r, 298}^{0}$ values for the other phases in Table $8 \mathrm{can}$ be similarly computed following the three steps given in this appendix. For example, one must: 1) accept "best" values for $\Delta \mathrm{H}_{\mathrm{f}, 298}^{0}$ and $\mathrm{S}_{298_{+}}^{0}$ for $\mathrm{Mg}, \mathrm{Mg}^{+2}$, and merwinite $\left[\mathrm{Ca}_{3} \mathrm{Mg}\left(\mathrm{SiO}_{4}\right)_{2}\right]$; 2) compute $\Delta \mathrm{G}_{\mathrm{f}, 298}^{\mathrm{O}}$ for $\mathrm{Mg}^{+2}$ and merwinite from these values and those previously selected in Table A.1; and 3) calculate a $\log _{10} K_{r, 298}^{0}$ for the dissolution reaction for merwinite (Table 8 ) using these $\Delta G_{f}^{0}, 298$ values for $\mathrm{Mg}^{+2}$ and merwinite and the previously calculated $\Delta G_{f, 298}^{0}$ values (STEP 2) for $\mathrm{Ca}^{+2}$ and $\mathrm{H}_{4} \mathrm{SiO}_{4}^{\circ}$. This procedure creates a set of thermodynamic data that are internally consistent with the accepted primary $\Delta H_{f, 298}^{0}$ and $S_{298}^{0}$ values.

\section{REFERENCES}

Ball, J. W., D. K. Nordstrom and E. A. Jenne. 1980. "Additional and Revised Thermochemical Data and Computer Code for WATEQ2 - A Computerized Chemical Model for Trace and Major Element Speciation and Mineral Equilibria of Natural Waters" U.S. Geol. Survey, Water-Resources Investigations 78-116, Menlo Park, California. 



\section{DISTRIBUTION}

No. of

Copies

OFFSITE

27 DOE Technical Information Center

Don Alexander

U.S. Nuclear Regulatory Commission

MS 905-SS

High Level Waste Tech. Development

Washington, DC 20555

John A. Apps

Lawrence Berkeley Laboratory

University of California

One Cyclotron Road

Building 90/1140C

Berkeley, CA 94720

Argonne National Laboratory

Reference Library

9800 South Cass Avenue

Argonne, IL 60439

10
No. of

Copies

Larry Benson

Lawrence Berkeley Laboratory

University of $\mathrm{Cal}$ ifornia

One Cyclotron Road

Building 90/1140G

Berkeley, CA 94720

George Birchard

Nuc lear Regulatory Commission

Off ice of Nuclear Research

Mailstop 1130-SS

Washington, DC 20555

Dr. John Bird

Geology Department

Cornel1 University

Ithaca, NY 14853

Ernest Bondietti

Environmental Sciences Division Oak Ridge National Laboratory Bldg. 1505

Oak Ridge, TN 37830

A. Brandstetter

Off ice of Nuclear Waste Isolation

Battelle Memorial Institute

505 King Avenue

Columbus, $\mathrm{OH} 43201$

Brookhaven National Laboratory

Reference Section

Information Division

Upton, Long Island, NY 11973

Douglas G. Brookins

Department of Geology

University of New Mexico

Albuquerque, NM 87131 
No. of

Copies

Harry C. Burkholder

Office of Nuclear Waste I solation

Battelle Memorial Institute

505 King Avenue

Columbus, $\mathrm{OH} 43201$

J. L. Burnett

DOE Office of Basic Energy

Sciences

Washington, DC 20545

Wayne Carbiener

Office of Nuclear Waste

I solation

Battelle Memorial Institute

505 King Avenue

Columbus, $\mathrm{OH} 43201$

Leslie Casey

DOE-NPO

$505 \mathrm{King}$ Avenue

Columbus, $\mathrm{OH} 43201$

H. Clyde Claiborne

Oak Ridge National Laboratory

P.0. Box $X$

Oak Ridge, TN 37830

Jess Cleveland

Denver Federal Center

U.S. Geological Survey

P.0. Box 25046

MS -412

Lakewood, C0 80225

Peter Col umbo

Brookhaven National Laboratory

Nuc lear Waste Management Group

Upton, NY 11973

Carl R. Cooley

DOE Division of Waste Isolation Washington, DC 20545
No. of

Copies

Jared Davis

U.S. Nuc lear Regulatory

Commission

Washington, DC 20555

Stan Davis

6549 W. Box Cyn Dr.

Tuc son, $A Z 85705$

Les Dole

Oak Ridge National Laboratory

P.0. Box $X$

Oak Ridge, TN 37830

R. G. Dosch

Sandia Laboratories

Division 4512

A lbuquerque, NM 87185

Geoffrey Eichholz

Regent's Professor of Nuclear Eng ineering

School of Nuclear Engineering Georgia Institute of Technology

Atlanta, GA 30332

Warren Eister

DOE Division of Waste Isolation

Washington, DC 20545

Environmental Protection Agency

Office of Radiation Programs

Technical Assessment Division AW559

Washington, DC 20460

Bruce R. Erdal

Los Alamos Scientific Laboratory

CNC-11, MS -514

Los Alamos, NM 87545

Sherman Fried

Argonne National Laboratory

9700 South Cass Avenue

Argonne, IL 60439 
No. of

Copies

A. Friedman

Argonne National Laboratory

9700 South Cass Avenue

Argonne, IL 60439

Alex Gancarz

Los Alamos Scient if ic Laboratory

CNC-11, Mailstop 514

Los Alamos, NM 87545

Robert G. Garvin

E. I. duPont deNemours Co.

Savannah River Laboratory

Aiken, SC 29801

Richard L. Hahn

Oak Ridge National Laboratory

P.0. Box $X$

Oak Ridge, TN 37830

R. J. Hall

Office of Nuclear Waste

Isolation

Battelle Memorial Institute

505 King Avenue

Columbus, $\mathrm{OH} 43201$

Phillip Helmke

1525 Observatory Dr.

University of Wisconsin

Madison, WI 53706

Bill Highland

Dames \& Moore

Suite 200

250 E. Broadway

Salt Lake City, UT 84717

Peter Hoffman

Office of Nuclear Waste

I sol ation

$505 \mathrm{King}$ Avenue

Columbus, $\mathrm{OH} 43201$

H. D. Holl and

Dept. of Geological Sciences

Harvard University

Cambridge, MA 02138
No. of

Copies

Norman Hubbard

Office of Nuclear Waste

I solation

Battelle Memorial Institute

$505 \mathrm{King}$ Avenue

Columbus, $\mathrm{OH} 43201$

Dana Isherwood

Lawrence Livermore Laboratory

P.0. Box 808

MSL-224

Livermore, CA 94550

J. K. Johnstone

Sandia Laboratories

A lbuquerque, NM 87107

G. R. Kilp

Advanced Energy System Division Westinghouse Electric Corp.

P.0. Box 10864

Pittsburgh, PA 15236

John F. Kircher

Office of Nuclear Waste Isolation

Battelle Memorial Institute

505 King Avenue

Columbus, $\mathrm{OH} 43201$

George A. Kolstad

DOE Division of Energy Research

Washington, DC 20545

Kurt Kraus

110 Ogontz Lane

Oak Ridge, TN 37830

Don Langmuir

Dept. of Ehcmistry and Geochemistry

Colorado School of Mines

Golden, C0 80401 
No. of

Copies

Ron Lantz

Intera Environmental Consultants

11999 Katy Freeway

Suite 610

Houston, TX 77079

R. B. Laughon

Office of Nuclear Waste Isolation

Battelle Memorial Institute

505 King Avenue

Columbus, $\mathrm{OH} 43201$

Lawrence Berkeley Laboratory

Reference Library

University of California

Berkeley, CA 94720

Lawrence Livermore Laboratory

Reference Library

P.0. Box 808

Livermore, CA 94550

Stan E. Logan

Los Almos Technical Associates, Inc.

P.0. Box 410

Los Alamos, NM 87544

Tom Longo

DOE Division of Waste I solation

Washington, DC 20545

Los Alamos Scientific Laboratory

Reference Library

P.0. Box 1663

Los Alamos, NM 87544

Richard W. Lynch

Manager, Department 4530

Sandia Laboratories

P.0. Box 5800

Albuquerque, NM 87185

I. Wendell Marine

E. I. duPont DeNeumours Co.

Savannah River Laboratory

Aiken, SC 29801
No. of

Copies

J. B. Martin

Asst. Director for Radioactive Waste Mgmt. Branch

NRC Division of Materials and

Fuel Cycle Facility Licensing

Washington, DC 20555

Jeff $L$. Means

Battelle Columbus Laboratory

$505 \mathrm{King}$ Avenue

Columbus, $\mathrm{OH} 43021$

Robert E. Meyer

Oak Ridge National Laboratory

P.0. Box X

Oak Ridge, TN 37830

Mart in A. Molecke

Nuc lear Waste Experimental Programs

Division 4512

Sandia Laboratories

Albuquerque, NM 87185

J. E. Monsees

Office of Nuclear Waste I sol at ion

Battelle Memorial Institute

$505 \mathrm{King}$ Avenue

Columbus, $\mathrm{OH} 43201$

J. B. Moody

Office of Nuclear Waste

I solation

Battelle Memorial Institute

505 King Avenue

Columbus, $\mathrm{OH} 43201$

Jim P. Murray

Harvard University

Pierce Hall

Cambridge, MA 02138

R. L. Nebeter

Exxon Nuclear Idaho

P.0. Box 2800

Idaho Fal ls, ID 83401 
No. of

Copies

Jeff 0 . Neff

DOE Columbus Program Office

$505 \mathrm{King}$ Avenue

Columbus, $\mathrm{OH} 43201$

Jim Neiheisel

Environmental Protection Agency

CM-2, Office of Radiation

Program, ANR 460

Washington, EC 20460

Edward Norris

Los Alamos Scientific Laboratory

Group CNC-11 MS-514

P.0. Box 1663

Los Alamos, NM 87545

E. J. Nowak

Sandia Laboratory

Division 5824

Albuquerque, NM 87131

Oak Ridge National Laboratory

Central Research Library

Document Reference Section

Oak Ridge, TN 37830

Edward O'Donnell

U.S. Nuclear Regulatory

Commission

Office of Standards Development

Washington, DC 20555

W. M. Pardue

Office of Nuclear Waste

Isolation

Battelle Memorial Institute

$505 \mathrm{King}$ Avenue

Columbus, $\mathrm{OH} 43201$

George A. Parks

St anford University

Department of Applied Earth

Sciences

Stanford, CA 94305
No. of

Copies

L. D. Ramspott

Lawrence Livermore Laboratory

P.0. Box 808

Livermore, CA 94550

Gary A. Robbins

Department of Geology

Texas A\&M University

College Station, TX

John B. Robertson

USGS National Center

Office of Radiohydrology

MS -410

Reston, VA 20292

R. A. Robinson

Office of Nuclear Waste I solation

Battelle Memorial Institute

$505 \mathrm{King}$ Avenue

Columbus, $\mathrm{OH} 43201$

Savannah River Laboratory

Reference Library

Aiken, SC 29801

Martin Seitz

Argonne National Laboratory

9700 South Cass Avenue

Argonne, IL 60439

Robert Silva

Lawrence Berkeley Laboratory

University of California

One Cyclotron Road

Building 70A/1160

Berkeley, CA 94720

David B. Stewart

National Center 959

U.S. Geological Survey

Reston, VA 22092

Daryl Tweeton

U.S. Bureau of Mines

P.0. Box 1660

Twin Cities, MN 55111 
No. of

Copies

Robert L. Watters

DOE Division of Ocological Sciences

Washington, DC 20545

H. Weed

$L$ awrence $L$ ivermore Laboratory

P.0. Box 808, MS-L233

Livermore, CA 94550

Allen Weiss

Brookhaven National Laboratory

Building 830

Upton, NY 11973

William B. White

Materials Research Laboratory

Pennsylvania State University

University Park, PA 16802

R. F. Williams

Electric Power Research Institute

$3412 \mathrm{Hillview} \mathrm{Avenue}$

P.0. Box 10412

Palo Alto, CA 94303

W. A. Williams

Office of Radiation Programs

Environmental Protection Agency

Washington, DC 20460

Wilste Library

U.S. Nuclear Regulatory

Commission

Washington, DC 20555

P. S. Witherspoon

University of $\mathrm{California}$

Berkeley

Geologic Engineering

1842 Monterey Avenue

Berkeley, CA 94707
No. of

Copies

T. J. Wolery

$L$ awrence $L$ ivermore $L$ aboratory

P.0. Box 808

Livermore, CA 94550

Kurt Wolf sberg

Los Alamos Scient if ic Laboratory

CNC-11, MS-514

Los Alamos, NM 97545

B. Wood

Department of Geology

Arizona State University

Tempe, AZ 85281

H. Tom Yolken

National Bureau of Standards

Physics Building/B320

Washington, DC 20234

ONSITE

5 DOE Richland Operations Office

0. J. Elgert

H. E. Ransom

J. J. Schreiber

F. R. Standerfer

M. W. Shupe

9 Rockwell Hanford Operations

G. S. Barney

D. Brown

C. H. Delegard

R. B. Kasper

W. H. Price

R. C. Routson

P. F. Salter

M. J. Smith

M. I. Wood

Hanford Engineering Development Laboratory

R. J. Cash 
No. of

Copies

91 Pacific Northwest Laboratory

L. L. Ames

E. M. Arnold

D. J. Bradley

T. D. Chikalla

M. O. Cloninger

D. G. Coles

W. J. Deutsch

F. H. Dove

A. R. Felmy

J. S. Fruchter

G. W. Gee

D. C. Girvin

J. H. Jarrett

E. A. Jenne

T. L. Jones

F. N. Hodges

M. R. Kreiter

K. M. Krupka (45)

W. L. Kuhn

D. E. Larson

J. L. MCElroy/

R. E. Nightingale
No. of

Copies

G. L. McVay

J. E. Mendel

J. R. Morrey

P. R. Partch

R. A. Peters

D. Rai

J. F. Relyea

W. A. Ross

J. L. Ryan

A. P. Schwab

R. J. Serne

J. W. Shade

D. R. Sherwood

J. A. Stott lemyre

R. G. Strickert

J. L. Swanson

R. P. Turcotte/D. M. Strachen

R. W. Westerman

J. H. Westsik

Water and Land Resources

Library (2)

Technical Information

Library (3)

Publishing Coordination BE (2) 
$\because$

'

. 